\title{
Response surface methodology mediated optimization of Lignin peroxidase from Bacillus mycoides isolated from Simlipal Biosphere Reserve, Odisha, India
}

\author{
Subhashree Rath ${ }^{\dagger}$, Manish Paul ${ }^{\dagger}$, Hemanta Kumar Behera and Hrudayanath Thatoi ${ }^{*}$ (1)
}

\begin{abstract}
Background: Lignin is a complex polymer of phenyl propanoid units found in the vascular tissues of the plants as one of lignocellulose materials. Many bacteria secrete enzymes to lyse lignin, which can be essential to ease the production of bioethanol. Current research focused on the study of ligninolytic bacteria capable of producing lignin peroxidase (LiP) which can help in lignin biodegradation and bioethanol production. Ligninolytic bacterial strains were isolated and screened from the soil samples of Simlipal Biosphere Reserve (SBR), Odisha (India), for the determination of their LiP activity. Enzymatic assay and optimization for the LiP activity were performed with the most potent bacterial strain. The strain was identified by morphological, biochemical, and molecular methods.

Results: In this study, a total of 16 bacteria (Simlipal ligninolytic bacteria [SLB] 1-16) were isolated from forest soils of SBR using minimal salt medium containing lignin. Out of the 16 isolates, 9 isolates showed decolourization of methylene blue dye on LB agar plates. The bacterial isolates such as SLB8, SLB9, and SLB10 were able to decolourize lignin with $15.51 \%, 16.80 \%$, and $33.02 \%$, respectively. Further enzyme assay was performed using $\mathrm{H}_{2} \mathrm{O}_{2}$ as substrate and methylene blue as an indicator for these three bacterial strains in lignin containing minimal salt medium where the isolate SLB10 showed the highest LiP activity $(31.711 \mathrm{U} / \mathrm{mg})$. The most potent strain, SLB10, was optimized for enhanced LiP enzyme activity using response surface methodology. In the optimized condition of pH 10.5, temperature $30^{\circ} \mathrm{C}, \mathrm{H}_{2} \mathrm{O}_{2}$ concentration $0.115 \mathrm{mM}$, and time $42 \mathrm{~h}$, SLB10 showed a maximum LiP activity of $55.947 \mathrm{U} /$ $\mathrm{mg}$ with an increase of 1.76 times from un-optimized condition. Further chemical optimization was performed, and maximum LiP activity as well as significant dye-decolourization efficiency of SLB10 has been found in bacterial growth medium supplemented individually with cellulose, yeast extract, and $\mathrm{MnSO}_{4}$. Most notably, yeast extract and $\mathrm{MnSO}_{4}$-supplemented bacterial culture medium were shown to have even higher percentage of dye decolourization compared to normal basal medium. The bacterial strain SLB10 was identified as Bacillus mycoides according to morphological, biochemical, and molecular (16S rRNA sequencing) characterization and phylogenetic tree analysis.

Conclusion: Result from the present study revealed the potential of Bacillus mycoides bacterium isolated from the forest soil of SBR in producing LiP enzyme that can be evaluated further for application in lignin biodegradation and bioethanol production. Scaling up of LiP production from this potent bacterial strain could be useful in different industrial applications.
\end{abstract}

\footnotetext{
*Correspondence: hnthatoi@gmail.com

†Subhashree Rath and Manish Paul contributed equally to this work. Department of Biotechnology, Maharaja Sriram Chandra Bhanja Deo University, Takatpur, Baripada, Odisha 757003, India
}

(c) The Author(s) 2021. Open Access This article is licensed under a Creative Commons Attribution 4.0 International License, which permits use, sharing, adaptation, distribution and reproduction in any medium or format, as long as you give appropriate credit to the original author(s) and the source, provide a link to the Creative Commons licence, and indicate if changes were made. The images or other third party material in this article are included in the article's Creative Commons licence, unless indicated otherwise in a credit line to the material. If material is not included in the article's Creative Commons licence and your intended use is not permitted by statutory regulation or exceeds the permitted use, you will need to obtain permission directly from the copyright holder. To view a copy of this licence, visit http://creativecommons.org/licenses/by/4.0/. 
Keywords: Lignin, Lignin peroxidase, Bacillus mycoides, Dye decolourization, Enzyme activity, Response Surface methodology

\section{Background}

Fossil fuel serves as a major non-renewable source in global energy sector. It was a fundamental driver of the industrial revolution and the technological, social, and economic progress [1]. The excessive uses of this nonrenewable fuel in industrial and transportation process results in environmental pollution through emitting greenhouse gases that are responsible for the climate change and global warming [2]. Apart from these, the fossil fuel reservoir is also depleting fast due to its over exploitation and necessitates search for an alternative source of renewable energy to overcome the energy crisis in future. In this context, lignocellulosic biofuel forms an alternative energy source which can substitute fossil fuel. Versatile ligninolytic microorganisms can generate renewable energy fuels form the lignocellulosic biomass (LCB) and biological wastes which can diminish the threatening concern of environmental pollution to a large extent [3]. Among others, the most favourable substitute for fossil fuel is bioethanol. Bioethanol, a form of biofuel produced from plant biomass sources, is ecofriendly as well as has the potential to simultaneously replace conventional fossil fuels and reduce the environmental concerns. In recent years, the production of biofuels using various microorganisms (both bacteria and fungus) has been steadily increasing. Due to metabolic diversity, different microorganisms are capable of producing bioethanol from various substrates such as sugary, starchy, and lignocellulosic biomasses. However, LCB serves as a potential source of bioethanol that is economic and noncompetitive in comparison to food biomass [4].

LCB consist of cellulose, hemicellulose, and lignin, in which cellulose and hemicellulose are used for the production of bioethanol whereas lignin is considered as an impurity during bioethanol formation as it is a phenolic compound and contains no sugar in it [4-6]. Lignin present in the plant cell wall and one of the main components of all the vascular plant which serves as a structural constituent unit. This biopolymer acts as natural glue which holds cellulose and hemicellulose fibers together. It prevents easy accessibility of cellulase and hemicellulose enzymes towards their hydrolysis in the process of biofuel production. Therefore, lignin should be removed from cellulose and hemicellulose for maximum production of bioethanol. The separation of lignin from the LCB has several other advantages as it has many biotechnological and industrial applications. Chemical catalysts assisted lignin degradation, and thermochemical treatment requires severe chemical reaction conditions for highly efficient lignin depolymerization which causes damage to the environment. On the other hand, such adverse effect can overcome by using biological lignin depolymerization method that has now fascinated a growing consideration on lignin valorization [7].

The biological depolymerization process mainly involves the fungal-based degradation system and bacterial-based degradation system which are an efficient environment-friendly method for lignin valorization [7]. Therefore, research on the microorganism-based lignin degradation has received great attention [8]. Fungus and bacteria produce numbers of ligninase enzymes such as lignin peroxidase, manganese peroxidase, laccase, dye decolourizing peroxidase, and versatile peroxidasesignificant enzyme for the degradation of lignin from LCB. Liginin peroxidase is one of the most well-known abundant and significant ligninase enzyme produced by many microorganisms including bacteria $[5,6]$. Lignin peroxidase (LiP) (EC 1.11.1.14) enzyme belongs to the family of oxidoreductase that catalyzes the cleavage of different bonds present in lignin polymer using hydrogen peroxidase $\left(\mathrm{H}_{2} \mathrm{O}_{2}\right)$ as oxygen acceptor [5]. The first LiP was discovered in white rot fungus Phanerochaete chrysosporium in its extra cellular medium [9]. Later isoforms of LiP are found in other fungi such as Tinea versicolor, Phanerochaete sordida, Phlebia radiate, Phelibia tremellosa, Lentinula edodes, Sporotrichum pulverulentum, Pycnoporus cinnabarinus, Phelibia tremiellosus, Pleurotus sp., and Coriolus versicolor [10, 11]. Apart from these fungi, the bacterial LiP enzymes involve in lignin degradation acquired great attention due to their heterologous expression compared with fungal ones [12]. There has been reported that the LiP enzymes mainly produced in Actinomycetes, $\alpha$-proteobacteria, and $\gamma$-proteobacteria can degrade lignin efficiently [13].

The in vitro microbial LiP production mainly depends upon various physical and environmental parameters like carbon/nitrogen ratio, acidity or alkalinity of medium, presence of metal ions, temperature, incubation time, and oxygen content in the medium [12]. In the microbial LiP-mediated oxidative depolymerization process of lignin, LiP catalyzes the cleavage of different bonds present in lignin polymer using hydrogen peroxidase $\left(\mathrm{H}_{2} \mathrm{O}_{2}\right)$ as an oxygen acceptor [5]. However, it has been reported that only some higher fungi and bacteria are effective in the degradation of lignin polymer through this oxidative reaction process. Although in-depth studies regarding 
this mechanism have been carried out repeatedly in the past 20 years, the mechanism has not yet been fully interpreted. To understand this brief mechanism of enzymemediated biodegradation of lignin, studies on the enzyme activity and its stimulatory factors should be undertaken. Optimization of growth factor to enable maximum production and activity of enzyme is mostly significant in this essence. Till date, most of the optimization studies for LiP have been reported only for fungal sources [14-18]. In case of ligninolytic bacteria, some reports are available on their isolation, characterization, and identification from different sources like decaying plant materials and soil samples [19-24]. However, the optimization of growth factors for the maximum lignin peroxidase activity from bacteria is infrequent and needs extensive studies.

Based on the current scenario, an attempt has been made to isolate ligninolytic bacteria from Similipal Biosphere Reserve (SBR), Odisha (India), and evaluate their LiP activity. The Similipal Biosphere Reserve located in the northern most part of Odisha extends over an area of $5578 \mathrm{~km}^{2}$ covering three districts, Mayurbhanj, Keonjhar, and Balasore. Its humid monsoon weather provides suitable conditions for the growth of numerous flora fauna and microorganisms [25]. The forest soils of SBR contain lignocellulosic leaf litter materials which provide a suitable habitat for the growth of ligninolytic microorganisms. Previous studies have reported the occurrence of cellulase- and xylanase-producing microorganisms from soils of SBR [26, 27]. It is apparent that lignin-degrading microorganism will be potentially available in forest soils contaminated with high content of decompose lignocellulosic materials. Based on the background, the present study is directed towards isolating, screening, and characterizing the most potent ligninolytic bacteria from SBR soil samples for evaluating lignin peroxidase activity which can be utilized for bioethanol and other value added product formation. Further, the optimization of LiP activity from the most efficient ligninolytic bacterium using response surface methodology was performed in a view to explore the use of isolated strain for the production of bioethanol from lignocellulosic waste.

\section{Methods}

\section{Collection of soil sample}

The soil samples underneath the plant mixed with scraps of decaying bark were freshly collected randomly under aseptic condition from 2 to $10 \mathrm{~cm}$ below the surface area. The soil samples were collected from seven different selected sites of Sitakunda and Lulung regions of SBR forest area situated in Mayurbhanj district of Odisha, India. SBR is a natural forest positioned at the latitude of $21^{\circ} 10^{\prime}$ to $22^{\circ} 12^{\prime} \mathrm{N}$ and longitude of $85^{\circ} 58^{\prime}$ to $86^{\circ}$ $42^{\prime} \mathrm{E}$ and expanded over a reserve forest area of $2750 \mathrm{~km}^{2}$ [24]. About $1 \mathrm{~cm}$ of the uppermost layer of the soil was taken out before collection of the sample. Each soil samples were put in a sterile zip locked polythene bags with proper labeling. These bags were packed in ice box and brought to the laboratory for the storage at $4 \pm 0.1^{\circ} \mathrm{C}$ for future analysis.

\section{Isolation of ligninolytic bacteria Preparation of alkali lignin}

The dried barks of tree Peltophorum pterocarpum (Radha chuda) were collected as a source of lignin. The barks were grinded to turn them into powder form followed by the acid pretreatment. To perform the acid pretreatment, $5 \mathrm{ml}$ of $1 \%$ sulphuric acid was added to $10 \mathrm{~g}$ of grinded powder and heated at $80^{\circ} \mathrm{C}$ for $20 \mathrm{~min}$. The acid pretreated solution was then allowed to reach room temperature so that the lignocellulosic mass can be obtained. Then, $100 \mathrm{ml}$ of $4 \%$ sodium hydroxide was added in the cool down acid pretreated solution and boiled for $30 \mathrm{~min}$. The solution was then filtered and autoclaved and finally stored in the freeze for future use as stock solution [28].

\section{Isolation of bacteria using alkali lignin}

The lignin-degrading bacteria were isolated using lignin enriched minimal salt medium (MSM-L) in which previously prepared alkali lignin served as the sole carbon and energy source. To prepare $1 \%$ alkali lignin solution, $1 \mathrm{ml}$ of previously prepared stock solution (Alkali lignin) was added with $99 \mathrm{ml}$ of distilled water. MSM-L consisted of $1 \%$ alkaline lignin minimum salt medium solution which contained (g/L): $\mathrm{K}_{2} \mathrm{HPO}_{4}, 4.55 ; \mathrm{KH}_{2} \mathrm{PO}_{4}, 0.53 ; \mathrm{MgSO}_{4}$, 0.5 ; and $\mathrm{NH}_{4} \mathrm{NO}_{3}, 5[29,30]$. Enriched culture were prepared in a $250-\mathrm{ml}$ Erlenmeyer flask by placing $5 \mathrm{~g}$ sample in $95 \mathrm{ml}$ of autoclaved MSM-L, and the culture were incubated at 30 to $45^{\circ} \mathrm{C}$ at $120 \mathrm{rpm}$ for 7 days. One milliliters enriched sample was transferred to $99 \mathrm{ml}$ of sterile water. Using $1 \mathrm{ml}$ of the liquid mixture, serial dilution technique was performed from each dilution. About $100 \mu \mathrm{l}$ of serially diluted $10^{-6}$ sample were spread on plate containing MSM-L. The plates were incubated at $30^{\circ} \mathrm{C}$ for 7 days until colonies developed. The isolated bacteria were plated onto fresh MSM-L agar plates repeatedly to obtain pure cultures [31]. Different sub colony was selected according to morphological characteristic like shape, size, and colour. Morphologically isolated and distinguished bacteria colony from the pour plate of each soil sample was transferred to MSM-L agar medium and incubated at $37^{\circ} \mathrm{C}$ for 3 days. This method was repeated until single and pure bacterial culture was obtained [28]. Pure bacterial cultures were designated as Simlipal Ligninolytic Bacteria (SLB), and for the convenience of work, all bacterial isolates were named in abbreviated form as 
SLB1, SLB2, SLB3 up to the total number of occurrence for all future contexts.

\section{Screening of ligninolytic bacteria Qualitative assay of ligninolytic activity}

The bacterial isolates were screened using methylene blue dye as an indicator. The bacteria possessing ligninolytic enzymes undergo oxidation of the indicator dye. Methylene blue is a phenolic compound and retains the homologous chemical structure like the subunits found in lignin polymer. Ten microliters $\left(6.2 \times 10^{9} \mathrm{CFU} / \mathrm{ml}\right)$ of each bacterial broth was inoculated inside a 4-mm pore made on the Luria broth (LB) agar plate containing methylene blue dye. The LB agar medium contains $(\mathrm{g} / \mathrm{L})$ $\mathrm{NaCl}$ : 1, tryptone: 2, yeast extract: 1 , agar: 2 , and methylene blue dye: 0.25 . Ten microliters distilled water was used as a control in the LB agar plate. The plates with the bacterial inoculums were incubated at $30^{\circ} \mathrm{C}$ for $72 \mathrm{~h}$. The agar plates were monitored daily for bacterial growth and decolourization of methylene blue dyes [32]. Occurrence of any bacterial growth on LB agar plate (colony diameter, $\mathrm{C}$ ) and appearance of hydrolyzing zone $(\mathrm{H})$ around the bacterial growth due to the decolourization of methylene blue dye was monitored daily to determine the ligninolytic activity by measuring its diameter. For the determination of $\mathrm{H}$ to $\mathrm{C}$ value, the ratio of hydrolyzing zone and colony diameter were measured individually for each bacterial strain.

\section{Quantitative assay of ligninolytic activity}

Quantitative assay was carried out to quantify the decolourization of lignin broth which indicates the growth of ligninolytic bacteria in the lignin broth. Bacterial isolates that have shown highest ligninolytic activity in the screening using methylene blue indicator were taken in this quantitative assay. All the selected isolates for the first phase of quantitative assay were freshly inoculated in $50 \mathrm{ml}$ of $0.5 \%$ lignin broth in a $250-\mathrm{ml}$ flask, and an un-inoculated control was also kept. All the flasks were incubated at $30^{\circ} \mathrm{C}$ at $120 \mathrm{rpm}$ for 7 days in a shaker incubator, and absorbance was recorded on daily up to 7 days at a wavelength of $465 \mathrm{~nm}$ in UV-Vis spectrophotometer (Systronic-119) [33]. All the experiments have been performed in triplicates. The percentage of decolourization for each isolate was calculated using the Eq. 1:

$$
\text { Percentage of decolourization }=\frac{(\text { A465 on 1st day }- \text { A465 on 7th day })}{\text { A465 of control on } 7 \text { th day }} \times 100
$$

A465 $=$ Absorbance at wavelength $465 \mathrm{~nm}$.

\section{LiP enzyme assay}

The isolates (SLB8, SLB9, and SLB10) that showed significant percentage of decolourization in the quantitative assay were further selected for the lignin peroxidase enzyme assay. LiP activity can be determined on the basis of demethylation of methylene blue dye. Methylene blue serves as an indicator in this enzyme assay, and the enzyme LiP demethylates methylene blue in the presence of $\mathrm{H}_{2} \mathrm{O}_{2}$. The final product is a tri-demethylated methylene blue derivative known as azure $\mathrm{C}$, and the reaction occurs at $\mathrm{pH} 4$. Enzyme activity was determined as per the percent decolourization of the methylene blue dye. About $1 \mathrm{ml}$ of culture broth of each isolates were taken in the Eppendorf tubes, and the culture broths were centrifuged at $4{ }^{\circ} \mathrm{C}$ at $7000 \mathrm{rpm}$ in cooling centrifuge. The supernatant from each centrifuge tubes were then collected for conducting the enzyme assay as the lignin peroxidase is an extracellular protein. In $1 \mathrm{ml}$ of $50 \mathrm{mM}$ sodium potassium tartarate ( $\mathrm{pH}-4)$ buffer, $0.1 \mathrm{ml}$ of $0.1 \mathrm{mM} \mathrm{H}_{2} \mathrm{O}_{2}$ inducer was added. Then to this solution, $32 \mu \mathrm{M}$ methylene blue and $10 \mu \mathrm{l}$ of enzyme supernatant were added. In this assay, $10 \mu \mathrm{l}$ of distilled water was added with the above reaction mixture in place of enzyme supernatant in a separate test tube as control. The final assay solution was incubated for $1 \mathrm{~h}$ at room temperature and absorbance was measured in UV-Vis spectrophotometer (Systronic-119) at a wavelength of $650 \mathrm{~nm}$ [34]. All the experiments have been done in triplicates. The results were elucidated as the percentage decolourization of methylene blue dye by the enzyme LiP in comparison with the control tube determined using the Eq. 2:

$$
\frac{(\mathrm{A} 650 \text { control }-\mathrm{A} 650 \text { for test })}{\text { A650for control }} \times 100
$$

A650 $=$ Absorbance at wavelength $650 \mathrm{~nm}$.

The most efficient ligninolytic bacterial strain obtained after the LiP enzyme assay would further be taken for all other experimental analyses like growth curve analysis; morphological, biochemical, and molecular identification; and optimization of bacterial LiP activity.

\section{Growth curve of bacterial isolate}

The bacterial population was calibrated after specific time intervals, and the number of viable bacteria is plotted in graph with respect to time, which gives a logarithmic growth curve. Overnight grown culture of $2 \mathrm{ml}\left(10^{4}\right.$ cell $/ \mathrm{ml}$ according to the dilution factor) of the ligninolytic bacterial isolate was inoculated in a $200 \mathrm{ml}$ of sterilized lignin broth at $37{ }^{\circ} \mathrm{C}$ for $42 \mathrm{~h}$ with continuous shaking. To obtain the growth curve in terms of viable cell counts, 
culture suspension was taken at a time intervals of $2 \mathrm{~h}$ followed by serial dilution and plating of aliquots to determine the CFU/ml.

\section{Identification of ligninolytic bacterium \\ Morphological characterization}

Morphological characterization includes the study about the morphology (size, shape, and texture) of the bacteria. To study different morphological features, Gram's stain of the ligninolytic bacterium was performed following the protocol as mentioned by Coico [35]. The bacterium was examined with a phase contrast microscope $(\times 100$ objectives) after Gram's staining.

\section{Biochemical characterization of ligninolytic bacterium}

The ligninolytic bacterium was further considered to perform different biochemical tests as listed in the Bergey's manual of Systematic Bacteriology for its identification purpose [36].

\section{Molecular identification of ligninolytic bacterium}

Molecular identification of ligninolytic bacterial strain was carried out by $16 \mathrm{~S}$ rRNA gene sequencing. DNA of the bacterium was extracted, and the 16S rRNA gene was amplified based on the standard methods using the universal primers [37]. Purification of the amplified $16 \mathrm{~S}$ rRNA gene was performed and sent to Applied Bioscience Eurofins, Bangalore, for its sequencing.

Preparation of phylogenetic tree To prepare the phylogeny tree of the bacterium, the construction of the contig $16 \mathrm{~S}$ rRNA gene is required. Contig sequence of $16 \mathrm{~S}$ rRNA gene of the ligninolytic bacterium was constructed with the help of CAP3 webserver [38]. In this purpose, the forward and reverse sequence information of that bacterium retrieved from 16S rRNA gene sequencing were used. Other closely related homologues sequences of $16 \mathrm{~S}$ rRNA genes with the contig sequence of the ligninolytic bacterium were retrieved from the nucleotide BLAST search [39]. The contig sequences along with all the retrieved sequences from BLAST search was compared both by the pairwise and multiple sequence alignment in ClustalW tool. Neighbour-joining (NJ) method was applied to prepare the phylogenetic tree for the ligninolytic bacterium in MEGA 7.0.26 (Molecular Evolutionary Genetics Analysis) software [40] using the output alignment file obtained from ClustalW. Percentage of homogeneity between the associated taxa containing the bacteria clustered together was determined by bootstrap test [41]. Maximum composite likelihood (MCL) method was used to calculate the evolutionary distances in phylogenetic tree [42].
Assessment of carbon, nitrogen, and metal sources in regulating lignin peroxidase activity

Selection of preferable carbon (glucose, fructose, starch, and cellulose) and nitrogen (tryptone, urea, peptone, ammonium nitrate, sodium nitrate, and yeast extract) sources that promote lignin peroxidase activity in the ligninolytic bacterium was done by culturing the bacterium separately in medium supplemented with different carbon and nitrogen sources at a concentration of $0.4 \%(\mathrm{w} / \mathrm{v})$. Different sources of metal ions $\left(\mathrm{KCl}, \mathrm{MgSO}_{4}\right.$, $\mathrm{MnSO}_{4}, \mathrm{ZnSO}_{4}, \mathrm{CuSO}_{4}, \mathrm{FeSO}_{4}, \mathrm{NaCl}, \mathrm{CaCl}_{2}, \mathrm{CoCl}_{2}$ ) were also individually applied to the bacterial growth medium at a concentration of $0.1 \%(\mathrm{w} / \mathrm{v})$ to analyze their impact in enzyme activity $[43,44]$. All the experiments in the above mentioned chemical optimization study have been performed in triplicates.

\section{Assessment of carbon, nitrogen, and metal sources in dye decolourization by lignin peroxidase}

Dye decolourizing ability by the LiP enzyme from the ligninolytic bacterium was performed by the quantitative assay as mentioned previously. In this purpose, the basal medium used for culturing the ligninolytic bacterium was individually supplemented by respective carbon, nitrogen, and metal ion sources as mentioned above to measure the enzyme activity.

\section{Optimization of lignin peroxidase enzyme activity Experiment design and statistical optimization of lignin peroxidase activity using response surface methodology (RSM)}

To study the combinatorial impact of the variables viz. incubation time, $\mathrm{pH}$, substrate concentration, and temperature on the activity of lignin peroxidase (LiP) enzyme, the Box-Behnken design was employed. Table 1 represents the range and three specific levels of the above mentioned variables that were optimized for maximizing the LiP activity. The low and high levels of each independent variable were marked as -1 and +1 , respectively, whereas the center level was coded as 0 [45]. The BoxBehnken design is preferable for the construction of both the quadratic response surfaces and a second-degree polynomial model. This second-degree polynomial model is

Table 1 Actual levels for the four variables Box-Behnken design

\begin{tabular}{lllll}
\hline Independent variables & Symbols & \multicolumn{2}{c}{ Coded and actual levels } \\
\cline { 3 - 5 } & & $\mathbf{- 1 \text { (low) }}$ & $\mathbf{0}$ & $\mathbf{+ 1 \text { (high) }}$ \\
\hline Incubation time $(\mathrm{h})$ & $\mathrm{A}$ & 12 & 42 & 72 \\
$\mathrm{pH}$ & $\mathrm{B}$ & 5.5 & 8.0 & 10.5 \\
Substrate conc $(\mathrm{mM})$ & $\mathrm{C}$ & 0.030 & 0.115 & 0.200 \\
Temperature $\left({ }^{\circ} \mathrm{C}\right)$ & $\mathrm{D}$ & 30 & 37.5 & 45 \\
\hline
\end{tabular}


applied to optimize a process in case of a small number of experimental runs [46]. The design of experimental models was performed using the Design-Expert (Version 12, Stat-Ease Inc., Minitab Inc., USA) statistical software on the basis of a second-degree polynomial equation which resulted 27 experimental runs. The second-degree polynomial is demonstrated as Eq. 3:

$$
\begin{aligned}
Y= & b_{0}+b_{1} A+b_{2} B+b_{3} C+b_{4} D+b_{12} A B+b_{13} A C+ \\
& b_{23} B C+b_{24} B D+b_{11} A^{2}+b_{22} B^{2}+b_{33} C^{2}+b_{44} D^{2}
\end{aligned}
$$

In the above equation, $Y$ represents the estimated response which actually depicts the lignin peroxidase (LiP) activity. In the present study, four factors viz, incubation time $(A)[12,42$, and $72(\mathrm{~h})] ; \mathrm{pH}(B)[5.5,8.0$, and 10.5]; substrate concentration $(C)[0.030,0.200$, and 0.115 $(\mathrm{mM})]$, and temperature $(D)\left[30,37.5\right.$, and $\left.45\left({ }^{\circ} \mathrm{C}\right)\right]$ were considered in the Box-Behnken design for measuring the LiP enzyme activity from the ligninolytic bacterium. In the second-degree polynomial equation mentioned above, $b_{0}$ indicates the inter shape or offset term; $b_{1}, b_{2}$, $b_{3}$, and $b_{4}$ are the terms responsible for linear affect; and $b_{11}, b_{22}, b_{33}$, and $b_{44}$ are interaction terms during the calculation of LiP activity. According to above mentioned equation, the RSM data were further subjected to regression analysis of variance to fit the model. Fit statistics of the response model for LiP activity of the ligninolytic bacterium was calculated. The adequacy of the resulting model was verified by model analysis and $R^{2}$ analysis. $F$ value was determined to check the statistical significance of the entire calculated model at $5 \%$ level of significance [47]. For the determination of the optimum condition for the highest lignin peroxidase activity, the fitted equation was presented as 3D surface plots, which is also constructed by the Design-Expert software.

\section{Culture of bacterium as per the experiment designed}

On the basis of experimental conditions designed in RSM, bacterial culture was made in a 250-ml Erlenmeyer flask containing culture broth MSM-L medium. The medium was composed of (g/L) $\mathrm{K}_{2} \mathrm{HPO}_{4}, 4.55 ; \mathrm{KH}_{2} \mathrm{PO}_{4}$, $0.53 ; \mathrm{MgSO}_{4}, 7 \mathrm{H}_{2} \mathrm{O}, 0.5$; and $\mathrm{NH}_{4} \mathrm{NO}_{3}, 5$ supplemented with $1 \%$ alkali lignin. The $\mathrm{pH}$ of the culture broth was set to 3 different variables $(5.5,8.0$, and 10.5). All the flasks filled with MSM-L culture broth were autoclaved followed by the addition of different concentrations $(\mathrm{g} / \mathrm{L})$ of $\mathrm{H}_{2} \mathrm{O}_{2}(0.030,0.115$, and 0.200$)$ as a substrate to measure LiP activity. Each flask was then inoculated with $0.5 \%$ (31 $\left.\times 10^{11} \mathrm{CFU} / \mathrm{ml}\right)$ of standard inoculum $(\mathrm{v} / \mathrm{v})$ of the ligninolytic bacterial strain. The inoculated flasks were then placed on a rotary shaker incubator with a shaking speed of $120 \mathrm{rpm}$ to incubate the bacterial culture at specific temperature $\left(30^{\circ} \mathrm{C}, 37.5^{\circ} \mathrm{C}\right.$, and $\left.45^{\circ} \mathrm{C}\right)$ and for specific time (12, 42 , and $72 \mathrm{~h})$ as mentioned in the experimental design in RSM.

\section{Quantitative estimation of LiP activity}

After the completion of incubation as mentioned above, incubated bacterial culture broth with a volume of $1 \mathrm{ml}$ from each flask was drawn in a separate Eppendorf tube for a specific experimental condition. All the Eppendorf tubes with $1 \mathrm{ml}$ of bacterial culture incubated under specific experimental condition were immediately transferred and kept inside an ice box to avoid the denaturation of enzyme. In the present study, LiP activity was calibrated in triplicate for each experimental condition. All Eppendorf tubes filled with $1 \mathrm{ml}$ of bacterial culture broth were centrifuged at $7000 \mathrm{rpm}$ for $10 \mathrm{~min}$ at $4{ }^{\circ} \mathrm{C}$. After the completion of centrifugation, the supernatants from each Eppendorf tube were collected to conduct the LiP enzyme assay for the estimation of LiP activity [48]. Triplicate samples were used during the LiP activity estimation for each experimental condition as mentioned in the RSM. The LiP activity calculated from each experimental condition was then taken for the preparation of $3 \mathrm{D}$ surface plots and carrying out of the regression analysis and analysis of variance (ANOVA).

\section{Results}

\section{Isolation of ligninolytic bacteria}

In this study, a dark brown coloured homogeneous solution of alkali lignin was prepared (Fig. 1). Enriched minimum salt medium containing the freshly prepared alkali lignin (MSM-L) was used for the growth of ligninolytic bacterial colonies in the pour plates. After incubating the plate at $37^{\circ} \mathrm{C}$ for $72 \mathrm{~h}$, different bacterial colonies were obtained using morphological characteristics like size, shape, margin, and colour. A total of 16 ligninolytic bacterial colonies were isolated using pour plate method after serial dilution, from the rhizospheric soil samples collected from SBR and were named as SLB1 to SLB16.

\section{Screening of ligninolytic bacteria}

All the 16 bacterial isolates were primarily screened for ligninolytic activity using methylene blue dye as an indicator. The bacteria possessing ligninolytic enzymes are able to oxidize the indicator dye methylene blue and decolourize the dye (Fig. 2). Among the 16 ligninolytic bacterial strains isolated from the soil samples, 9 isolates showed ligninolytic activity which was measured as per the $\mathrm{H}$ to $\mathrm{C}$ value $(\mathrm{H}$-hydrolyzing zone, $\mathrm{C}$-colony diameter). Comparative $\mathrm{H}$ to $\mathrm{C}$ values showed the maximum decolourization zone diameter of the bacterial strain 


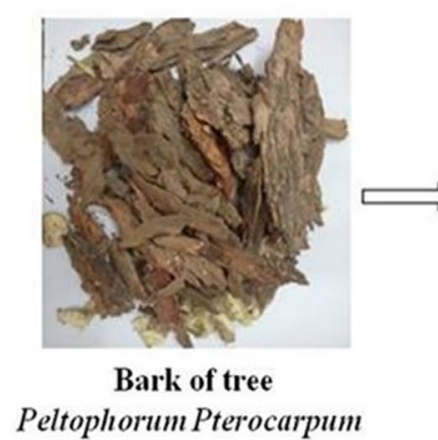

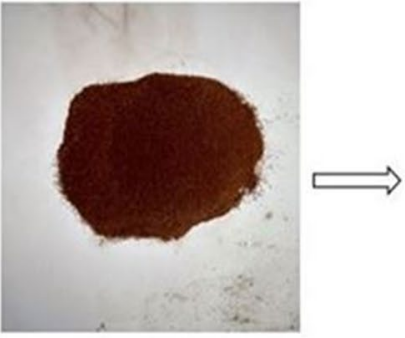

powder of the bark

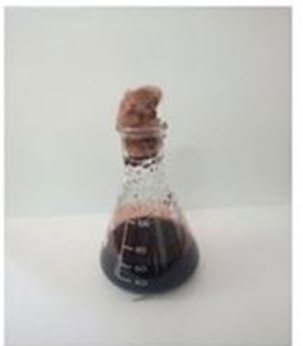

Alkali lignin

Fig. 1 Preparation of alkaline lignin

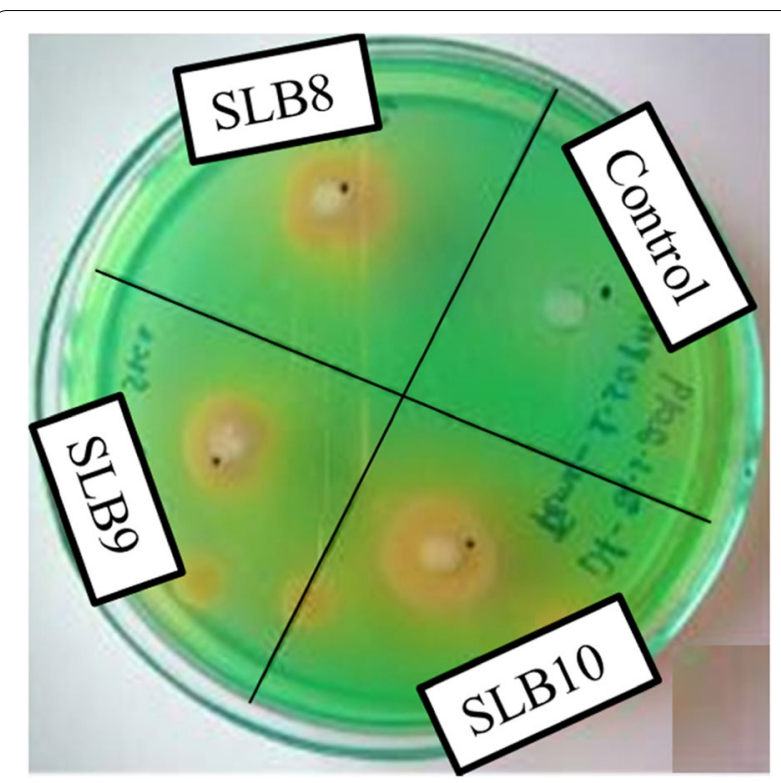

Fig. 2 Screening of ligninolytic bacterial isolates on LB agar medium containing methylene blue dye showing zone of decolourization for the bacterial isolates SLB8, SLB9, and SLB10

SLB10 with a value of 1.38 followed by SLB9, SLB8, and SLB1 with $\mathrm{H}$ to $\mathrm{C}$ values of $1.36,1.33$, and 1.21 , respectively. The range of the $\mathrm{H}$ to $\mathrm{C}$ values recorded for the ligninolytic bacteria was between 1.05 and 1.38 .

\section{Quantitative assay for ligninolytic activity}

From the primary screening, three bacterial strains (SLB8, SLB9, and SLB10) which showed the most H to C ratio among all were selected for the quantitative assay for ligninolytic activity. Absorbance values of the lignin containing culture broth inoculated with those ligninolytic bacteria were measured at a daily interval for 7 days after the inoculation. Among all these 3 isolates, SLB8 showed the highest absorbance of 0.781 at day 1 which gradually decreases to 0.649 at day 7 . SLB9 showed comparatively less absorbance value of 0.752 at day 1 which decline to 0.609 at day 7. Whereas, strain SLB10 presented the minimum absorbance of 0.745 at day 1 among all these 3 isolates which decreased to the lowest absorbance value of 0.571 at day 7 . In reference with the absorbance value (0.851) of the control (un-inoculated lignin broth), the percentage of decolourization was measured for each isolates. The result exhibited that SLB10 has the highest lignin decolourization efficiency with a value of $33.02 \%$ compared to the other two isolates which has a decolourization percentage of $15.51 \%$ and $16.80 \%$ for SLB8 and SLB9, respectively.

\section{Enzyme assay for lignin peroxidase}

The enzyme lignin peroxidase demethylates methylene blue in the presence of $\mathrm{H}_{2} \mathrm{O}_{2}$. According to the result obtained from the primary screening, 3 bacterial isolates $v i z$. SLB8, SLB9, and SLB10 were selected for the lignin peroxidase enzyme assay. From this enzyme assay and in the aspect of \% decolourization of the dye methylene blue, the isolate SLB10 showed the highest activity with a value of $31.711 \mathrm{U} / \mathrm{mg}$ (Fig. 3). The other isolates, SLB8 and SLB9, showed comparatively lower lignin peroxidase activity with the values of $13.590 \mathrm{U} / \mathrm{mg}$ and $16.609 \mathrm{U} / \mathrm{mg}$, respectively.

\section{Growth curve analysis for SLB10 isolate}

The changes in the number of bacterial population over time for the isolate SLB10 is obtained from a logarithmic growth curve (Fig. 4). It can be observed from the logarithmic growth curve that the lag phase of the bacterium lasts still $4 \mathrm{~h}$ after the incubation. At the end of the lag phase, the $\log _{10} \mathrm{CFU} / \mathrm{ml}$ value of culture medium was recorded as 6.8389. The exponential phase of the bacterium was continued after the $4 \mathrm{~h}$ and lasted for just before $16 \mathrm{~h}$ of the incubation with a change of $\log _{10} \mathrm{CFU} /$ $\mathrm{ml}$ value from 6.8389 to 7.2443 . The stationary phase of the bacterium was obtained between the 16 and $24 \mathrm{~h}$ of 


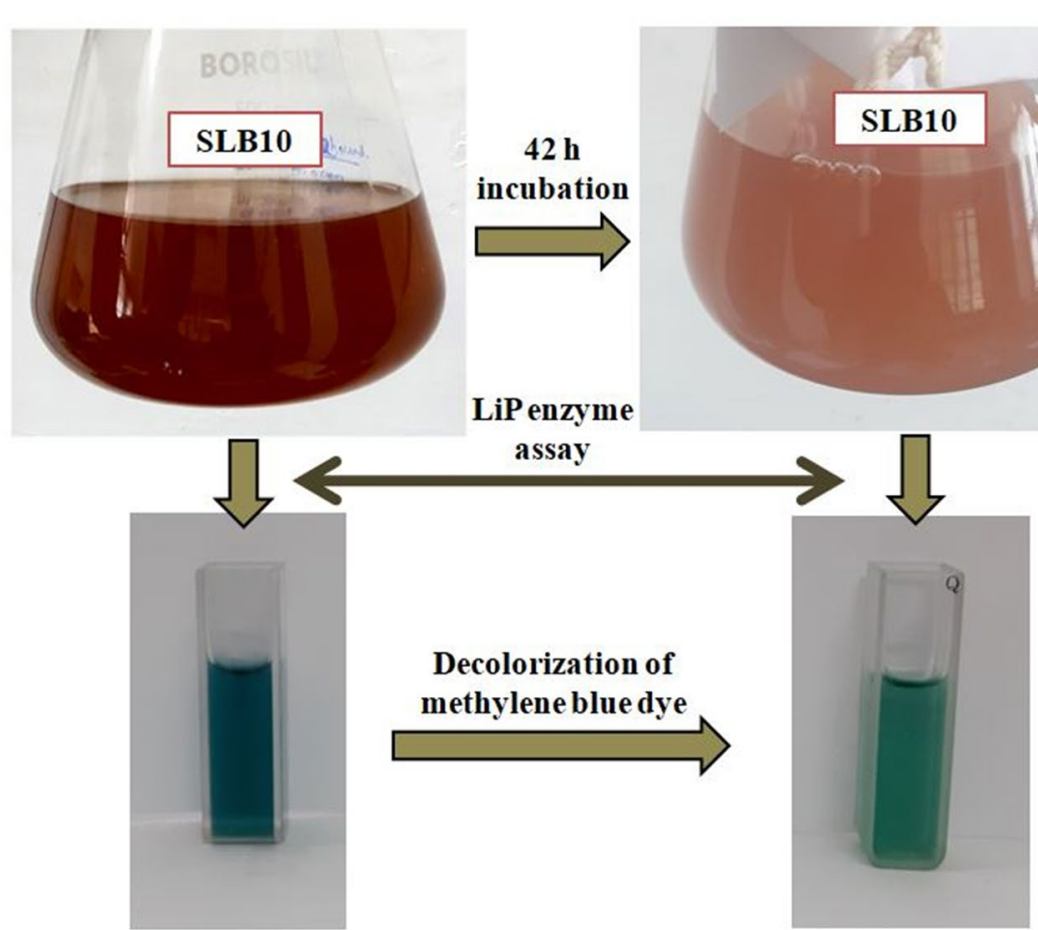

Fig. 3 Growth of the bacterium SLB10 in the culture flask containing MSM-L medium and the cuvettes showing the pattern of dye decolonization of methylene blue during LiP enzyme assay

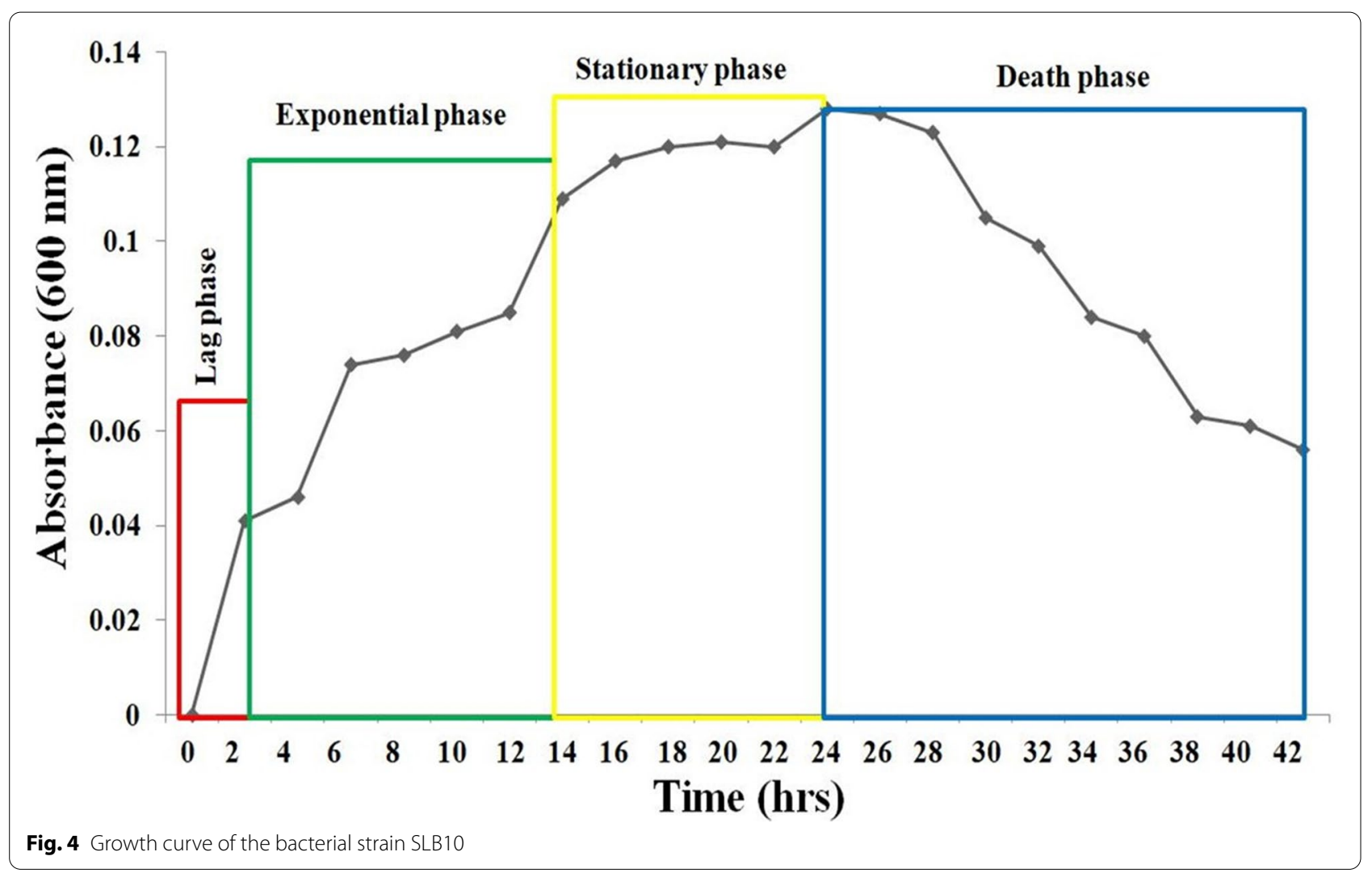


the incubation and the $\log _{10} \mathrm{CFU} / \mathrm{ml}$ value ranges from 7.2443 to 7.2833 . The death phase shown to be started after $24 \mathrm{~h}$ of incubation, and at the end of $42 \mathrm{~h}$ of incubation, the $\log _{10} \mathrm{CFU} / \mathrm{ml}$ value declined near 6.9243 .

\section{Morphological and biochemical characterization of SLB10 isolate}

In morphological characterization, texture of the bacterial colony, shape of the bacterial cell, and the pattern of gram staining of the bacterium were identified. The colony of SLB10 bacterium appeared to be in a form of elongated hairy with characteristic swirls. The bacterium was shown to have a rod-shaped structure and gram-positive characteristics when observed under microscope followed by staining procedure. Different biochemical tests were also conducted to obtain more information regarding the identification of the ligninolytic strain SLB10. The bacterium SLB10 exhibited a positive response in urease test as the colour of the medium changes to pinkish red after the bacterial inoculation. In both the oxidase and catalase tests, the SLB10 bacterium showed negative reaction as the colour of the broth remain unchanged after a few seconds and there is no formation of gas with white bubble as in case of oxidase and catalase test respectively. In methyl red test, the bacterium SLB10 gave a positive indication by transforming the colour of the growth medium in red. The strain SLB10 exhibited a positive result in VogesProskauer test as the broth developed a crimson yellow colour. In carbohydrate metabolism test, a positive indication has been observed for the bacterium SLB10 as the colour of the growth medium changed to yellow with the formation of gas. In case of both the citrate utilization test and triple sugar iron test, the bacterium SLB10 presented negative response as there is change of bacterial agar slant colour into blue and red in case of citrate utilization test and triple sugar iron test, respectively. As per the results obtained from all the morphological and different biochemical tests and references from Bergey's manual of Systematic Bacteriology, the ligninolytic bacterium SLB10 was primarily identified as a member belonging from the genus Bacillus.

\section{Molecular identification of SLB10 isolate}

Result obtained from the analysis of 16S rRNA gene sequencing has shown that the ligninolytic bacterium SLB10 has forward and reverse partial sequences with a length of 946 and $755 \mathrm{bp}$, respectively.

\section{Analysis of phylogenetic tree for SLB10 isolate}

Neighbour-Joining method was carried out to prepare the phylogenetic tree with the help of $16 \mathrm{~S}$ rRNA sequence information of SLB10 for the species level identification of the bacterium. According to the result of phylogenetic analysis, it has been found that the $16 \mathrm{~S}$ rRNA gene sequence alignment of isolate SLB10 is intimately linked with Bacillus mycoides strain 273 with a percentage of homogeneity value of 99 which is the highest among all compared (Fig. 5). From the phylogeny tree, it can be also observed that due to the lowest evolutionary distance, the tested ligninolytic bacterium SLB10 and the closed homologues Bacillus mycoides strain 273 are clustered together under the CLADE-I. Therefore, based on the analysis from 16S rRNA gene sequencing and phylogeny tree, the SLB10 strain was recognized as Bacillus mycoides.

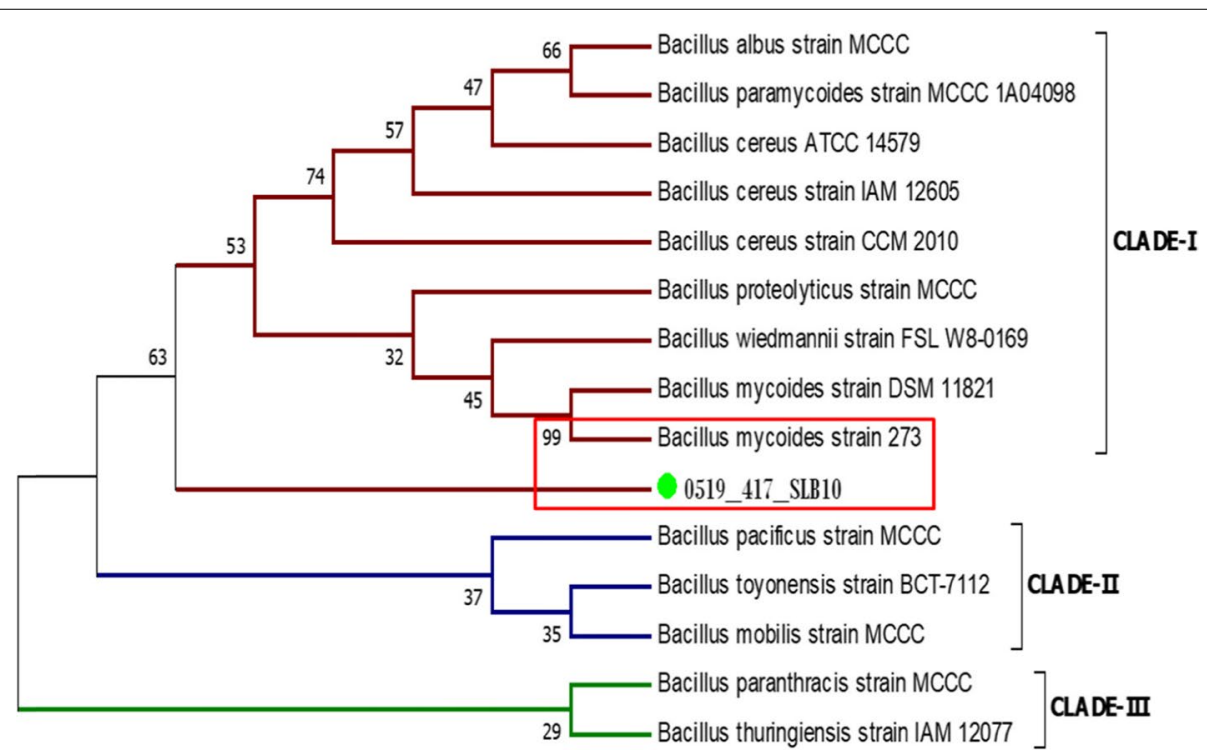

Fig. 5 Phylogenetic tree of the ligninolytic strain SLB10 based on 16S rRNA sequence 

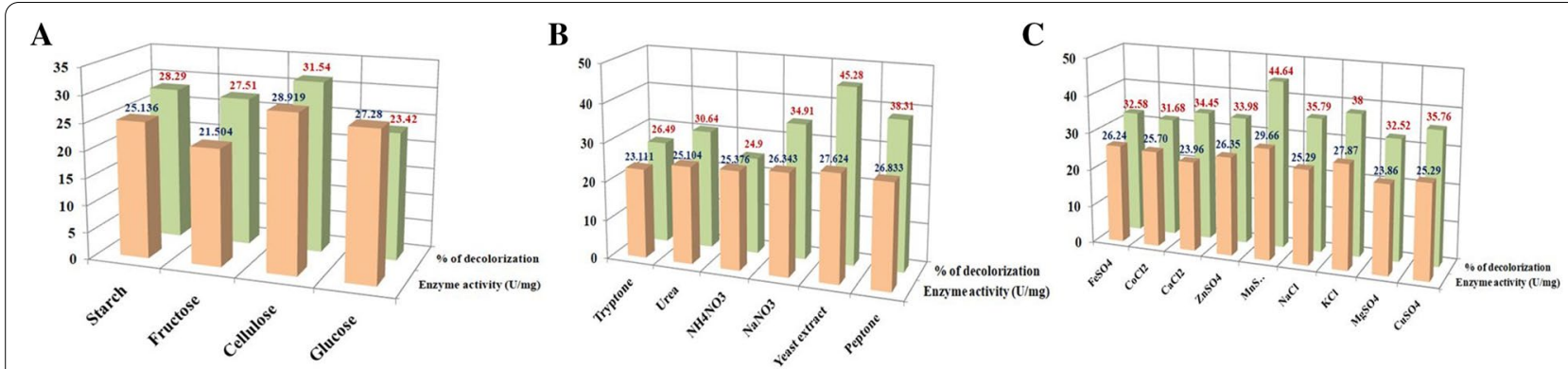

Fig. 6 Effect of different carbon sources (a), nitrogen sources (b), and metal ion sources (c) on LiP activity and dye decolourization by the bacterium Bacillus mycoides

\section{Optimization of lignin peroxidase enzyme activity}

For the optimum bacterial growth and its enzyme function, various inorganic nutrients such as carbon, nitrogen, and metal ion sources are necessary. Therefore, experiments have been carried out to determine the impact of carbon, nitrogen, and metal ions on the lignin peroxidase activity of the bacterium Bacillus mycoides. Effect of these carbon, nitrogen, and metal ion sources on the ability of dye decolourization mediated by lignin peroxidase (LiP) of B. mycoides has also been determined. In addition to maximize the LiP activity of B. mycoides, optimization of multiple parameters including $\mathrm{pH}$, temperature, substrate concentration, and incubation time during the bacterial growth was performed on the basis of experiments designed by response surface methodology (RSM).

\section{Effect of carbon sources on LiP activity and dye-decolourization}

The effect of various carbon sources on LiP activity of $B$. mycoides was carried out in the same basal medium and culture conditions. Analysis the result from this experiment depicted that highest LiP activity of $28.919 \mathrm{U} / \mathrm{mg}$ has been recorded in the presence of cellulose in basal medium in comparison with the presence of other three carbon sources viz. starch $(25.136 \mathrm{U} / \mathrm{mg})$, fructose $(21.504 \mathrm{U} / \mathrm{mg})$, and glucose $(27.280 \mathrm{U} / \mathrm{mg}$ ) (Fig. 6). This result implied that cellulose might have some inducing effect in promoting lignin peroxidase activity. In terms of percentage of dye decolourization for different carbon sources, it has been found that highest decolourization of $31.54 \%$ was recorded in case of cellulose supplemented medium for B. mycoides (Figs. 6 and 7). Followed by cellulose other three carbon sources viz. starch, fructose, and glucose supplemented bacterial growth medium showed dyedecolourization percentage of $28.29,27.51$, and $23.42 \%$, respectively (Fig. 6).

\section{Effect of nitrogen sources on LiP activity and dye decolourization}

The function of the enzyme is also greatly influenced by one of the key causes, which is a separate source of nitrogen. In this study, maximum LiP activity has been found in case of yeast extract supplemented basal medium with a value of $27.624 \mathrm{U} / \mathrm{mg}$ followed by other two nitrogen sources, peptone $(26.833 \mathrm{U} / \mathrm{mg})$ and sodium nitrate (26.343 U/mg), respectively. Comparatively, reduced enzymatic activity has been recorded for the nitrogen sources $v i z$. tryptone $(23.111 \mathrm{U} / \mathrm{mg})$, urea $(25.104 \mathrm{U} / \mathrm{mg})$, and $\mathrm{NH}_{4} \mathrm{NO}_{3}(25.376 \mathrm{U} / \mathrm{mg})$ when these were presence in the basal medium for bacterial culture (Fig. 6). Likewise, highest LiP activity in yeast extract supplemented bacterial growth medium a maximum dye-decolourization ability of $45.28 \%$ has been recorded. Peptone supplemented bacterial growth medium showed the second highest dye-decolourizing efficacy with a percentage of 38.31 (Figs. 6 and 7). Other four nitrogen sources supplemented medium showed dye-decolourization efficiency ranges between 24.9 and 34.91\% (Fig. 6).

\section{Effect of metal ion sources on LiP activity and dye decolourization}

Different metal ion sources have shown major effect in the variation of LiP activity. From the analysis of present study, it has been implied that the presence of $\mathrm{MnSO}_{4}$ and $\mathrm{KCl}$ in the basal medium of growth for $B$. mycoides resulted in comparatively higher LiP activity with the values of $29.659 \mathrm{U} / \mathrm{mg}$ and $27.872 \mathrm{U} / \mathrm{mg}$, respectively. Other tested metal ion sources has more or less similar impact on LiP activity which has been reflected by the range of enzyme activity value from $23.862 \mathrm{U} / \mathrm{mg}$ to $26.236 \mathrm{U} / \mathrm{mg}$ (Fig. 6). Presence of the metal ion source $\mathrm{MnSO}_{4}$ in bacterial growth medium showed the highest dye-decolourizing percentage of 44.64 compared to all other tested metal ion sources (Figs. 6 and 7). 


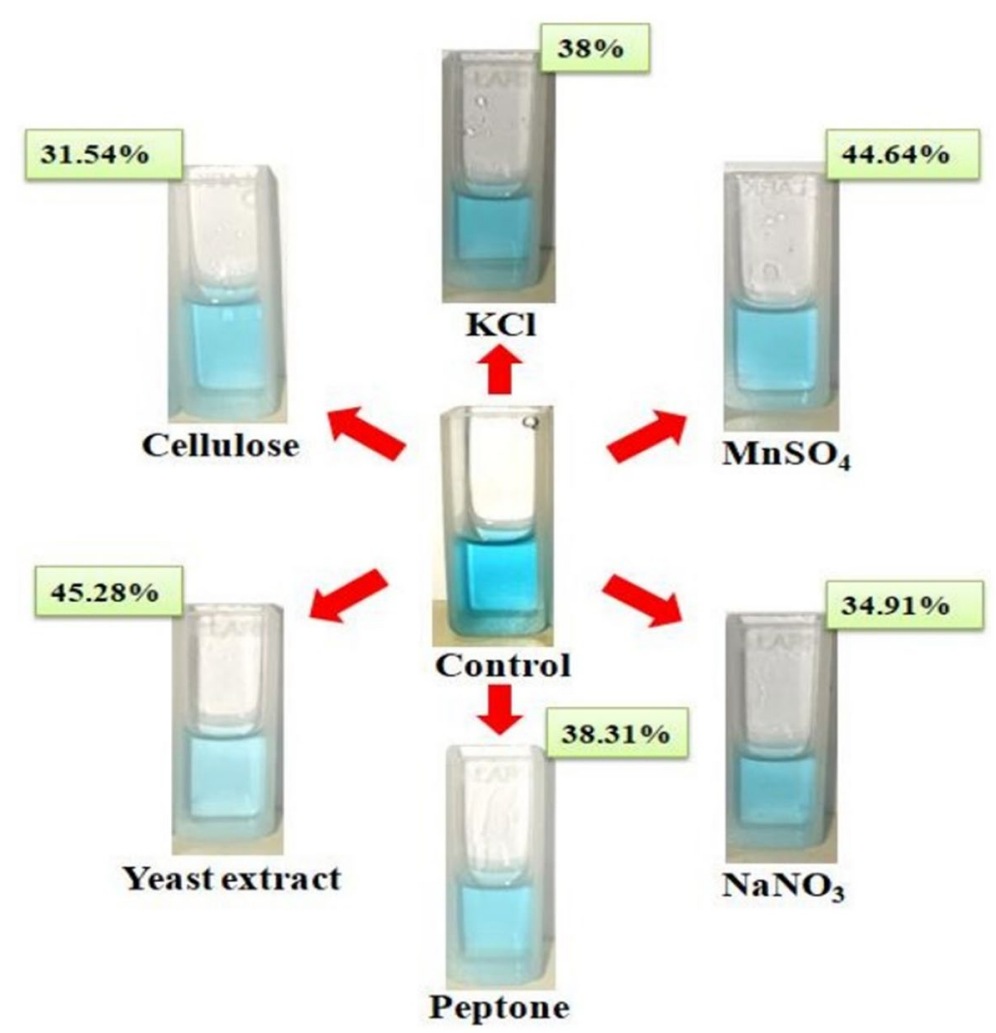

Fig. 7 Dye-decolourization pattern for the enzyme LiP from Bacillus mycoides cultured in different enriched media supplemented with cellulose, $\mathrm{KCl}, \mathrm{MnSO}_{4}$, peptone, $\mathrm{NaNO}_{3}$, and yeast extract. The percentage values indicate degree of dye decolourization in respective enriched media supplemented with specific carbon, nitrone, and meal ion sources

\section{Optimization of growth factors using RSM}

RSM was applied to detect the response of LiP activity for the ligninolytic bacterium Bacillus mycoides to various growth factors as mentioned above using Box-Behnken design. The full experimental plan as per the designed experiment condition along with the response values are given in the Table 2.

Regression analysis The second-order polynomial equation (Eq. 4) obtained from multiple regression analysis shown to explain LiP activity of the ligninolytic bacterial strain Bacillus mycoides looks like as follows:

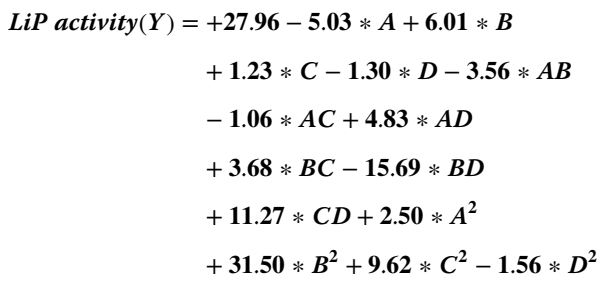

In the above mentioned equation, $Y$ indicates the response value of LiP activity of the bacterium Bacillus mycoides. $A, B, C$, and $D$ represented the incubation time, $\mathrm{pH}$, substrate $\left(\mathrm{H}_{2} \mathrm{O}_{2}\right)$ conc., and temperature, respectively. The polynomial equation implied that the terms $A, B, C, D, A B, A C, A D, B C, B D, C D, A^{2}, B^{2}, C^{2}$, and $D^{2}$ are significant in the designed experimental model for the expression of LiP activity as the calculated $p$ value for those terms are $<0.0001$ (Table 3). This result also represents the major impact of these parameters towards the highest coefficient value for LiP activity. The coefficient of variation $(\mathrm{CV})$ or the C.V. \% indicates the degree of precision with which the experimental conditions has been compared. A low CV value of $2.52 \%$ was calculated from the fit statistics in the response model of enzyme activity in RSM (Table 3).

Statistical analysis It is evident from the obtained result of statistical analysis that the quadratic model calculated by RSM was highly significant, as suggested by the model $F$ value $(55.92)$ and low probability value $(<0.0001)$. The lack of fit $F$ value of 0.4522 calculated in ANOVA indicates that this value has no major impact towards the 
Table 2 Optimization of fermentation parameters using response surface methodology with Box-Behnken design

\begin{tabular}{|c|c|c|c|c|c|c|}
\hline Conditions & $\mathrm{pH}$ & $\begin{array}{l}\text { Temperature } \\
\left({ }^{\circ} \mathrm{C}\right)\end{array}$ & Incubation time (h) & $\begin{array}{l}\mathrm{H}_{2} \mathrm{O}_{2} \text { conc. } \\
(\mathrm{mM})\end{array}$ & $\begin{array}{l}\text { LiP activity } \\
\text { experimental }(\mathrm{U} / \mathrm{mg})\end{array}$ & $\begin{array}{l}\text { LiP activity } \\
\text { predicted (U/ } \\
\text { mg) }\end{array}$ \\
\hline 1 & 5.5 & 45.0 & 42 & 0.115 & 28.241 & 27.563 \\
\hline 2 & 8.0 & 37.5 & 72 & 0.200 & 19.649 & 19.656 \\
\hline 3 & 8.0 & 45.0 & 42 & 0.200 & 37.155 & 36.369 \\
\hline 4 & 5.5 & 30.0 & 42 & 0.115 & 7.183 & 6.369 \\
\hline 5 & 8.0 & 37.5 & 72 & 0.030 & 16.631 & 15.369 \\
\hline 6 & 10.5 & 37.5 & 42 & 0.030 & 27.710 & 26.970 \\
\hline 7 & 8.0 & 30.0 & 42 & 0.200 & 9.400 & 9.633 \\
\hline 8 & 10.5 & 37.5 & 72 & 0.115 & 27.710 & 25.636 \\
\hline 9 & 8.0 & 30.0 & 72 & 0.115 & 13.596 & 13.756 \\
\hline 10 & 5.5 & 37.5 & 12 & 0.115 & 21.175 & 22.365 \\
\hline 11 & 10.5 & 37.5 & 12 & 0.115 & 34.189 & 40.220 \\
\hline 12 & 5.5 & 37.5 & 42 & 0.200 & 33.263 & 33.696 \\
\hline 13 & 10.5 & 45.0 & 42 & 0.115 & 30.240 & 30.256 \\
\hline 14 & 8.0 & 45.0 & 72 & 0.115 & 20.345 & 21.365 \\
\hline 15 & 5.5 & 37.5 & 42 & 0.030 & 39.315 & 39.698 \\
\hline 16 & 8.0 & 37.5 & 12 & 0.200 & 45.368 & 45.365 \\
\hline 17 & 10.5 & 30.0 & 42 & 0.115 & 55.947 & 54.639 \\
\hline 18 & 10.5 & 37.5 & 42 & 0.200 & 37.807 & 36.546 \\
\hline 19 & 8.0 & 30.0 & 42 & 0.030 & 33.263 & 33.658 \\
\hline 20 & 8.0 & 37.5 & 42 & 0.115 & 27.714 & 26.970 \\
\hline 21 & 8.0 & 45.0 & 42 & 0.030 & 13.135 & 13.750 \\
\hline 22 & 8.0 & 37.5 & 42 & 0.115 & 25.483 & 26.369 \\
\hline 23 & 5.5 & 37.5 & 72 & 0.115 & 25.702 & 25.639 \\
\hline 24 & 8.0 & 30.0 & 12 & 0.115 & 31.206 & 30.569 \\
\hline 25 & 8.0 & 45.0 & 12 & 0.115 & 16.630 & 16.840 \\
\hline 26 & 8.0 & 37.5 & 12 & 0.030 & 37.155 & 36.548 \\
\hline 27 & 8.0 & 37.5 & 42 & 0.115 & 24.789 & 25.658 \\
\hline
\end{tabular}

pure error which highlight that the designed experiment is mostly valid. According to the $p$ value of ANOVA table, there is a $95.13 \%$ chance that a lack of fit $F$ value becomes larger because of noise (Table 3$)$. The coefficient of determination $\left(R^{2}\right)$ was measured as 0.9722 in the fit statistics of the response model which indicates an enhanced LiP activity. This value represents that the statistical model in this study can elucidate $97.22 \%$ of variability in the response. In accordance with this reported statement, the $R^{2}$ value as calculated in this study suggests that the designed experiment appropriately predict the enzyme activity. The predicted $R^{2}$ value of 0.9073 has shown to be almost close with the adjusted $R^{2}$ value of 0.9548 in the fit statistics of response model (Table 3). This indicates a good agreement between the experimental and predicted values for LiP activity (Table 2). It has also been found that the adjusted $R^{2}(0.9548)$ is less than the $R^{2}$ value $(0.9722)$ as calculated in the present study (Table 3). Estimated $p$ value as derived from the coefficient table was reported as $<0.0001$ (Table 3) for the three experimental factors, substrate conc. $(C), \mathrm{pH}(B)$, and temperature $(D)$ among all interacting terms which implies the major impact of these three factors towards the highest LiP activity.

Interplay among variables Comparative effects of any two variables on LiP activity of Bacillus mycoides were explained by surface plots while holding the other values constant at the point values of different levels. From 3D response surface plots, the interactive effects of experimental factors on LiP enzymes activity were determined. The response surface curves Fig. 8a showed how LiP activity varied with the changes in $\mathrm{pH}$ and incubation time while maintaining the levels of temperature and substrate concentration fixed at $30^{\circ} \mathrm{C}$ and $0.115 \mathrm{mM}$, respectively. In this condition, it has been shown that increase in $\mathrm{pH}$ resulted in elevation of LiP activity from 
Table 3 Analysis of variance (ANOVA), Fit statistic of response model, and coefficient table for LiP enzyme activity of Bacillus mycoides

\begin{tabular}{|c|c|c|c|c|c|c|}
\hline \multicolumn{7}{|c|}{ Analysis of variance (ANOVA) } \\
\hline Source & Sum of squares & Degree of freedom & Mean square & $F$ value & $p$ value & \\
\hline Model & 2417.07 & 10 & 247.11 & 55.92 & $<0.0001$ & \\
\hline A-Incubation time & 303.55 & 1 & 303.55 & 68.69 & $<0.0001$ & \\
\hline $\mathrm{B}-\mathrm{pH}$ & 433.32 & 1 & 433.32 & 98.05 & $<0.0001$ & \\
\hline C-Substrate conc. & 18.12 & 1 & 18.12 & 4.10 & 0.0599 & \\
\hline D-Temperature & 20.40 & 1 & 20.40 & 4.62 & 0.0473 & \\
\hline$A B$ & 50.77 & 1 & 50.77 & 11.49 & 0.0037 & \\
\hline$A C$ & 4.48 & 1 & 4.48 & 1.01 & 0.3288 & \\
\hline$A D$ & 93.36 & 1 & 93.36 & 21.13 & 0.0003 & \\
\hline$B C$ & 54.06 & 1 & 54.06 & 12.23 & 0.0030 & \\
\hline$B D$ & 984.86 & 1 & 984.86 & 222.86 & $<0.0001$ & \\
\hline$C D$ & 508.14 & 1 & 508.14 & 114.98 & $<0.0001$ & \\
\hline$A^{2}$ & 698.77 & 1 & 698.77 & 87.20 & $<0.0001$ & \\
\hline$B^{2}$ & 448.76 & 1 & 448.76 & 682.5 & $<0.0001$ & \\
\hline$c^{2}$ & 831.56 & 1 & 831.56 & 144.55 & $<0.0001$ & \\
\hline$D^{2}$ & 1.99 & 1 & 1.99 & 0.4321 & $<0.0001$ & \\
\hline Residual & 95.23 & 16 & 8.08 & & & \\
\hline Lack of fit & 70.37 & 14 & 5.03 & 0.4522 & 0.9513 & \\
\hline Pure error & 0.3398 & 2 & 0.1699 & & & \\
\hline Cor total & 2541.78 & 26 & & & & \\
\hline \multicolumn{7}{|c|}{ Fit statistics of the response model } \\
\hline$R^{2}$ & Adjusted $R^{2}$ & Predicted $R^{2}$ & Adeq precision & C.V. \% & Standard deviation & \\
\hline 0.9722 & 0.9548 & 0.9073 & 32.3452 & 2.52 & 0.6194 & \\
\hline \multicolumn{7}{|c|}{ Coefficient table for lignin peroxidase activity } \\
\hline Interacting terms & $A B$ & $A C$ & $A D$ & $B C$ & $B D$ & $C D$ \\
\hline$p$ value & 0.0037 & 0.3288 & 0.0030 & 0.0030 & $<0.0001$ & $<0.0001$ \\
\hline
\end{tabular}

7.183 to $55.947 \mathrm{U} / \mathrm{mg}$ (Table 2). Figure $8 \mathrm{~b}$ represented the response surface curves which depicted that there was high LiP activity of $45.368 \mathrm{U} / \mathrm{mg}$ at substrate concentration $0.200 \mathrm{mM}$ and incubation time $42 \mathrm{~h}$ and low LiP activity of $25.483 \mathrm{U} / \mathrm{mg}$ at substrate concentration $0.115 \mathrm{mM}$ at $42 \mathrm{~h}$ (Table 2). The response surface curves shown in Fig. $8 \mathrm{c}$ represented that the LiP activity is regulated with the change of temperature and incubation time while the levels of $\mathrm{pH}$ and substrate concentration were kept unchanged. There was a peak in LiP activity recorded with the value of $55.947 \mathrm{U} / \mathrm{mg}$ at temperature $30^{\circ} \mathrm{C}$ and incubation time $42 \mathrm{~h}$. The lowest LiP activity of $25.483 \mathrm{U} / \mathrm{mg}$ was reported at temperature $37.5^{\circ} \mathrm{C}$ and incubation time $42 \mathrm{~h}$ in the same condition as above (Table 2). Figure 8d described the response surface curves in which LiP activity is regulated in respect with substrate concentration and $\mathrm{pH}$ where the levels of temperature and incubation time kept in fix. In this condition, the highest LiP activity of $55.947 \mathrm{U} / \mathrm{mg}$ at substrate concentration $0.115 \mathrm{mM}$ and $\mathrm{pH} 10.5$ has again been recorded.
Whereas, the lowest LiP activity of $25.483 \mathrm{U} / \mathrm{mg}$ was documented at substrate concentration $0.115 \mathrm{mM}$ and pH 8.0 (Table 2). The response surface curves in Fig. 8e also showed a high LiP activity of $55.947 \mathrm{U} / \mathrm{mg}$ at temperature $30^{\circ} \mathrm{C}$ and $\mathrm{pH} 10.5$. Likewise, as in the condition described in Fig. 8d, lowest LiP activity of $25.483 \mathrm{U} / \mathrm{mg}$ has been measured at temperature $37.5^{\circ} \mathrm{C}$ and $\mathrm{pH} 8.0$ in the condition maintained in Fig. 8e. Figure $8 \mathrm{f}$ shows the response surface curves in which LiP activity have shown in respect with substrate concentration and temperature where the levels of incubation time and $\mathrm{pH}$ were fixed. This experimental condition also demonstrated the maximum activity of LiP with a value of $55.947 \mathrm{U} / \mathrm{mg}$ at temperature $30^{\circ} \mathrm{C}$ and substrate concentration $0.115 \mathrm{mM}$ but a low $\mathrm{LiP}$ activity of $25.483 \mathrm{U} / \mathrm{mg}$ at temperature $37.5^{\circ} \mathrm{C}$ and substrate concentration $0.115 \mathrm{mM}$ (Table 2). The residual plot analysis (Fig. 9) of LiP activity of the ligninolytic bacterial strain Bacillus mycoides represented a high degree of agreement in both the predicted vs. actual responses. 
A

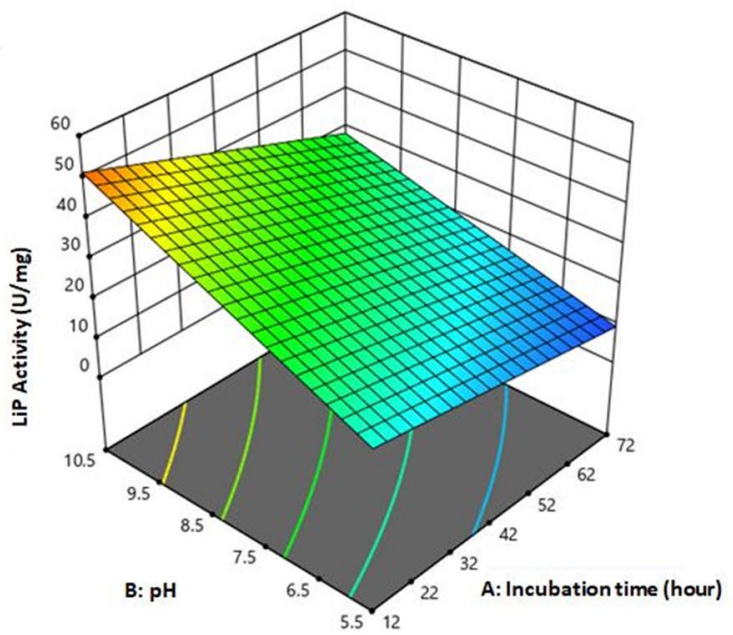

C

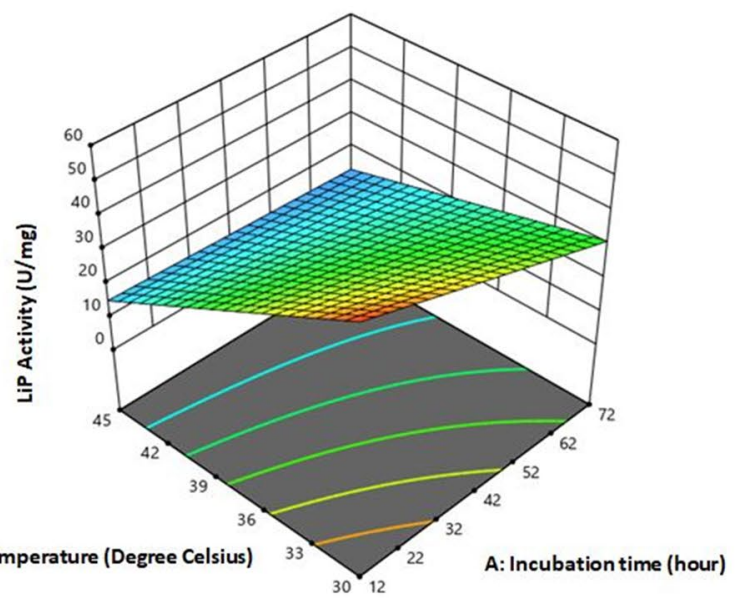

$\mathbf{E}$

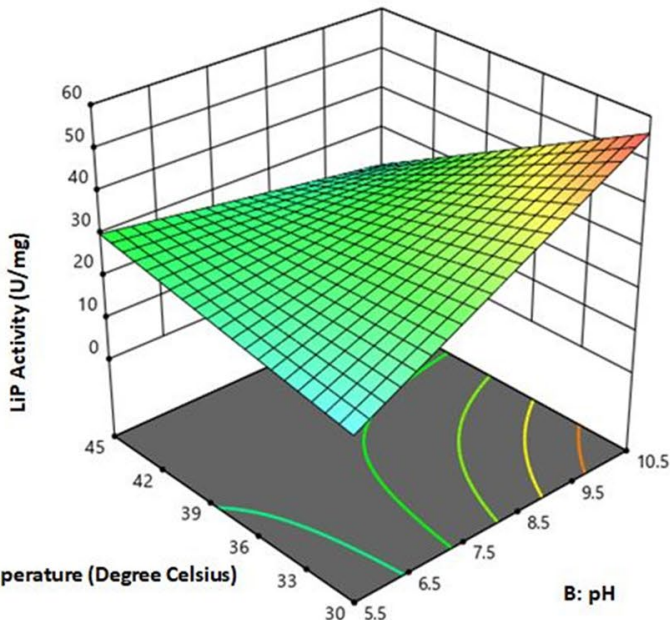

B

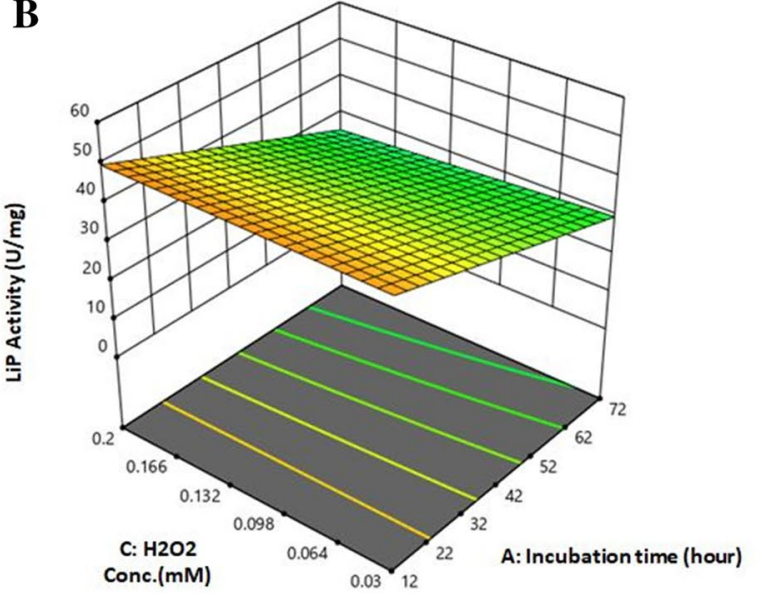

D
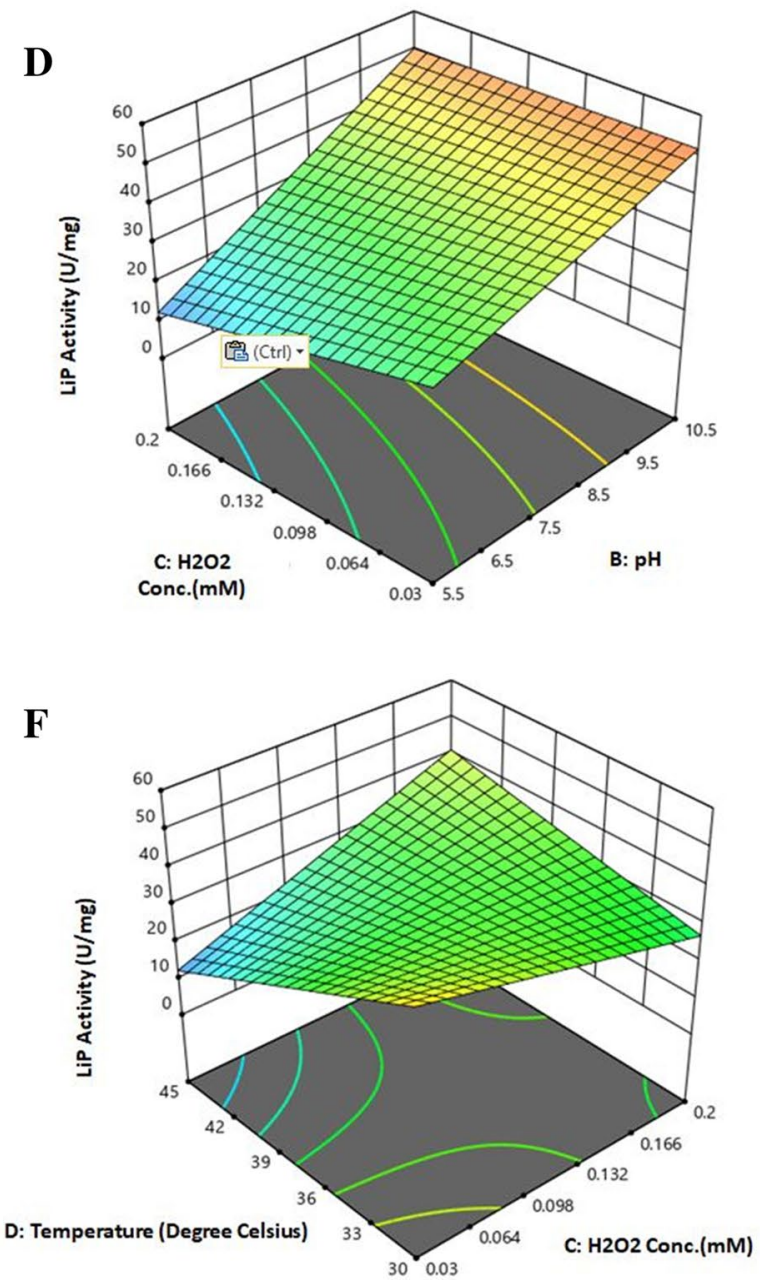

Fig. 8 Response surface graph of LiP activity of the ligninolytic bacterial strain Bacillus mycoides with respect to different experimental factor. a vs. $\mathrm{pH}$, incubation time; $\mathbf{b}$ vs. substrate concentration, incubation time; c vs. temperature, Incubation time; $\mathbf{d}$ vs. substrate conc., pH; e vs. temperature, incubation time; $\mathbf{f} v$ s. temperature, substrate conc 


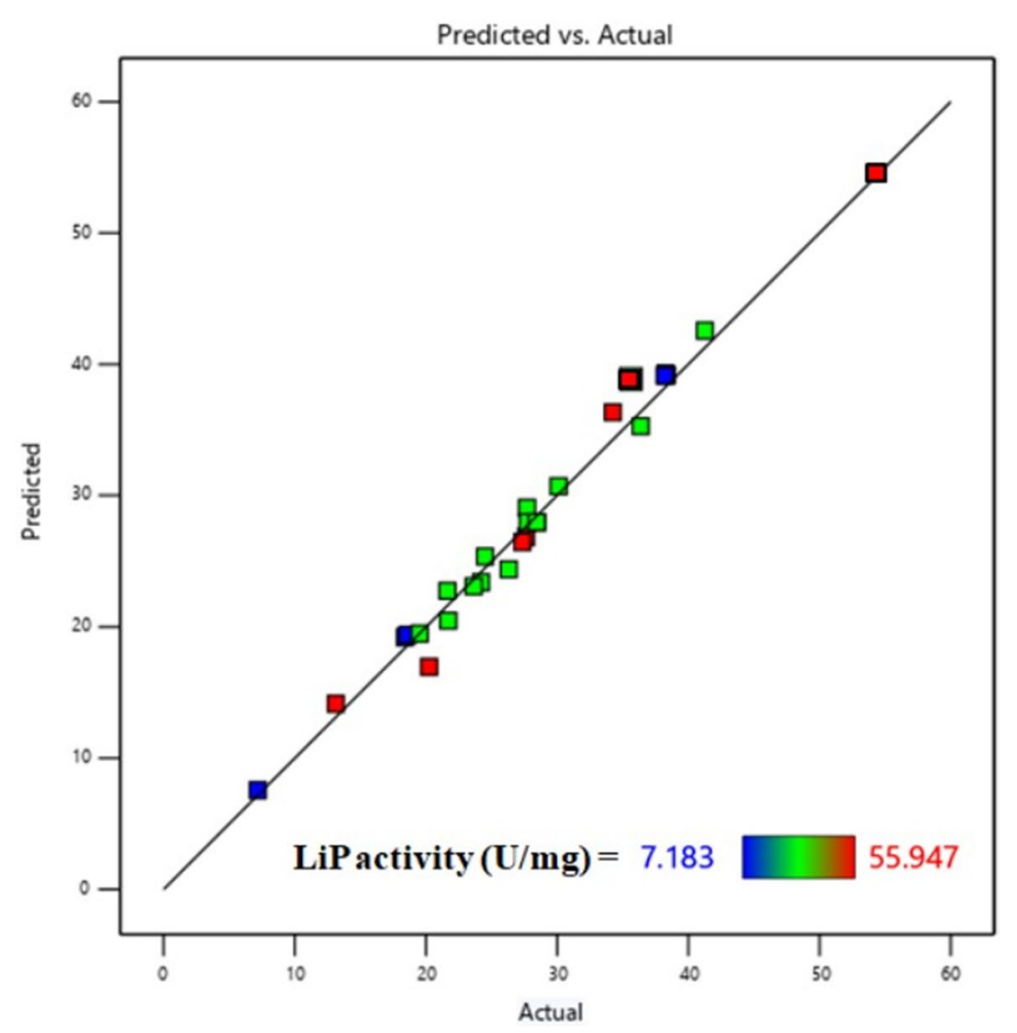

Fig. 9 Residual plots for the LiP activity of the ligninolytic bacterial strain Bacillus mycoides calculated from RSM

\section{Discussion}

The isolation of bacteria and screening of their enzyme production ability are important and primary steps to establish their applicability in biotechnological industries. In the current study, a number of ligninolytic bacteria were isolated from decomposed leaf litter containing forest soils of Simlipal Biosphere Reserve and evaluated for their ligninolytic activity primarily using methylene blue dye as indicator and secondarily by culturing in broth medium containing alkali lignin. Similar study was undertaken by Jadhav et al. [49] for isolation of ligninolytic bacteria from different sources such as decomposing plant material, compost feed-stock, and decaying bark sample from rhizospheric soil. There are reports which showed that a diverse bacterial community can be abundantly found in top surface of forest soils as they are rich in decomposed plant litter materials $[50,51]$. In the present study, 16 bacterial isolates were screened in LB agar medium containing methylene blue as an indicator for the determination of their ligninolytic activity. The bacterium SLB10 was found to show the highest decolourization zone with a percentage of 33.02 among all the screened bacterial strains. The present finding depicts the potential of highest lignin metabolism by SLB10 isolate and hence a possible higher LiP activity. Tian et al. [52], in their study, also screened some bacterial strains capable of metabolize lignin and lignin-related compounds for which they have used the methylene blue dye as an indicator in the bacterial growth medium for the screening purpose. Decolourizing effects of methylene blue, malachite green, and methyl orange catalyzed by the LiP enzyme from the fungus Phanerocheate chrysosporium was reported in the study of Alam et al. [53]. Their study revealed a maximum decolourization of $14 \%$ in case of methylene blue with compared to other two dyes which evidenced about the applicability of methylene blue effectively in the determination of dye decolourizing activity. The comparative decolourizing pattern as found in the present study and the investigation from Alam et al. illustrates that methylene blue can be used for determining the decolourization activity of both the bacterial and fungal LiP enzymes [53].

The bacterial isolates (SLB8, SLB9, and SLB10) were subsequently subjected to lignin peroxidase enzyme assay with a view to evaluate their comparative enzyme activity. From the results obtained from enzymatic assay of LiP, the highest activity has been noted for the isolate SLB10 with a value of $31.711 \mathrm{U} / \mathrm{mg}$. LiP assay was performed using $\mathrm{H}_{2} \mathrm{O}_{2}$ as substrate and methylene blue as an indicator. The same procedure for the enzyme assay 
of LiP was followed by Vignali et al. [54] where the LiP activity of $9.5 \mathrm{U} / \mathrm{mg}$ was recorded for the bacteria Rhodococcus jostii which is approximately 3.34 times less compared to the LiP activity determined in the present study.

A bacterial growth pattern has also been analysed in the current investigation which showed a change in the size of the bacterial population over the time in the culture for the isolate SLB10. The highest growth or population size for the bacterium SLB10 has been recorded after the $24 \mathrm{~h}$ of incubation with a viable cell count $\log _{10}$ $\mathrm{CFU} / \mathrm{ml}$ of 7.2833. Eastman et al. [55] has also studied the growth of Paenibacillus polymixa CR1 on lignin in presence of lignin in liquid culture with the terms of $\log _{10}$ $\mathrm{CFU} / \mathrm{ml}$ per hour. The result from their study presented that the growth of the bacterium reached a maximum after $40 \mathrm{~h}$ of incubation showing viable cell count $\log _{10}$ $\mathrm{CFU} / \mathrm{ml}$ of 7.2577 [56]. Therefore, in comparison with the result obtained from the study of Eastman et al., it can be stated that the strain SLB10 is an efficient strain capable of lignin biodegradation at a faster rate (maximum growth at $24 \mathrm{~h}$ of incubation) than that of bacterium Paenibacillus polymixa $\mathrm{CR} 1$ which took $40 \mathrm{~h}$ incubation time to reach maximum growth.

In order to determine the structure and chemical makeup of bacterial cell wall, gram staining method was presumed. The biochemical characterization was also carried out for the analysis of nutritional uptake and metabolic capabilities of bacteria using Bergey's Manual of Systematic Bacteriology. The results obtained from gram staining showed that the isolate SLB10 is a rod-shaped and gram-positive bacterium. Different biochemical characterization of the bacterium SLB10 exhibited positive results in urease test, methyl red test, Voges-Proskauer test, and carbohydrate test and negative results in catalase test, oxidase test, citrate utilization test, and triple sugar iron test. The above results indicate that the bacterium SLB10 belongs to the genus Bacillus. Morphological and biochemical identification of some ligninolytic bacterial isolates from Kuthrel agro field of Bhilai-Durg region, Raipur has also been performed in the study by Naz [24]. In their work, the isolates were identified as the genus of Bacillus and Streptomyces with reference to Bergey's Manual of Systematic Bacteriology. Those isolates were found to have the potential to tolerate high concentrations of lignin and production of ligninolytic enzymes.

Further, the 16S rRNA sequencing method was performed for the molecular identification of the bacterium SLB10 up to species level. Based on the sequencing and phylogenetic analysis showed that the bacterium SLB10 has the maximum homology with Bacillus mycoides and identified as Bacillus mycoides. In a similar type of study, Harith et al. [22] identified 8 ligninolytic bacteria and classified them as Klebsiella sp., Enterobacter sp., and Bacillus cereus on the basis of the partial sequence of $16 \mathrm{~S}$ rRNA gene. In another study, Abd-Elsalam and El-Hanafy [19] performed partial sequence of $16 \mathrm{~S}$ rRNA gene of some ligninolytic bacterial strains and identified two Bacillus strains such as Bacillus subtilis and Bacillus sp.. Therefore, it can be presumed that bacterial isolates belong to the genus Bacillus is common ligninolytic bacteria secreting LiP enzymes.

The chemical optimization of lignin peroxidase enzyme activity was conducted in presence of different inorganic nutrients like carbon, nitrogen, and metal ion sources. It was found from the current study that cellulose highly promotes the lignin peroxidase activity and maximizes the percentage of dye decolourization among all the carbon sources. Ramachandra et al. [56] in their study also reported an increased in lignin peroxidase activity in the presence of cellulose as carbon source where a higher consumption of hydrogen peroxidase has been noted during the catalytic reaction by the enzyme (Table 4). The effect of nitrogen source on LiP activity demonstrated the highest enzymatic turnover in case of yeast extract supplemented basal medium. Falade et al. [57] in their study reported that the composite effects of two nitrogen sources $v i z$. yeast extract and ammonium sulphate enhanced LiP activity of Bacillus sp. MABINYA-1. Therefore, from this observation, it can be implied that yeast extract have significant impact of increasing LiP activity when applied alone or in combination with other nitrogen source. Studies on the effect of metal ion sources on LiP activity revealed that both the $\mathrm{MnSO}_{4}$ and $\mathrm{KCl}$ have significantly upregulated the LiP activity. There is a report that manganese in the form of $\mathrm{MnCl}_{2}$ as a metal ion source can increase the LiP activity in case of bacterium Rhodococcus jostii (Table 4) [54]. Therefore, the results obtained from the present study and the findings from Vignali et al. are in well agreement with the fact that manganese ion play an important role in enhancing the LiP activity.

Further, in the present investigation, response surface methodology (RSM) was applied to optimize the culture conditions based on some important factors like $\mathrm{pH}$, temperature, substrate $\left(\mathrm{H}_{2} \mathrm{O}_{2}\right)$ concentration, and incubation time to get maximum LiP activity from Bacillus mycoides. In this study, the fit statistics calculation from the RSM indicates a low CV value which implied the designed experiment is highly reliable [63]. The $R^{2}$ value obtained from the designed experiment for the optimization of B. mycoides LiP activity has been found as 0.9722 which is much closer towards 1.0. Doddapaneni et al. [58] and Haaland [59] suggested that closer the value of $R^{2}$ to 1.0 , the stronger the model and the better it predicts the response of tested enzyme activity according to designed 
Table 4 Comparison of lignin peroxidase activity in different bacterial strains

\begin{tabular}{|c|c|c|c|c|c|}
\hline Bacteria & Substrate & $\begin{array}{l}\text { Optimal } \\
\text { physical } \\
\text { parameters }\end{array}$ & Optimal chemical sources & $\begin{array}{l}\text { Lignin peroxidase } \\
\text { activity }(\mathrm{U} / \mathrm{mg})\end{array}$ & References \\
\hline Rhodococcus jostii & $\mathrm{H}_{2} \mathrm{O}_{2}-0.1 \mathrm{mM}$ & $\begin{array}{l}\mathrm{pH}-6.0 \\
\text { Temp-37 }{ }^{\circ} \mathrm{C} \\
\text { Time-24h }\end{array}$ & $\mathrm{MnCl} 2-2 \mathrm{mM}$ & 9.5 & [50] \\
\hline Streptomyces viridosporus & 2,4-dicholorophenol-1.0mM & Time -3 days & Cellulose & 0.300 & {$[52]$} \\
\hline Bacillus sp. MABINYA-1 & $\begin{array}{l}\text { Kraft lignin } \\
\text { Saw dust } \\
\text { Maize Stover } \\
\text { Wheat straw }\end{array}$ & $\begin{array}{l}\mathrm{pH}-5.0 \\
\text { Temp-30 } \\
\text { Time }-72 \mathrm{C}\end{array}$ & $\begin{array}{l}\text { Glucose } \\
\text { Yeast extract-0.1g/L } \\
\text { Kraft lignin }-0.1 \% \mathrm{w} / \mathrm{V}\end{array}$ & $\begin{array}{l}17.50 \pm 0.10 \\
47.14 \pm 0.41 \\
37.09 \pm 0.00 \\
21.65 \pm 0.35\end{array}$ & [53] \\
\hline Ensifer adhaerens NWODO-2 & $\begin{array}{l}\text { Saw dust } \\
\text { Wheat straw } \\
\text { Corn stover }\end{array}$ & $\begin{array}{l}\mathrm{pH}-7.0 \\
\text { Temp-30 } \\
\text { Time- } 48 \mathrm{~h}\end{array}$ & NM & $\begin{array}{l}37.50 \\
5.25 \\
3.76\end{array}$ & [58] \\
\hline Nonomuraea gerenzanensis & $\begin{array}{l}\text { 2,6-Dimethyl phenol } \\
\mathrm{H}_{2} \mathrm{O}_{2} \\
\text { ABTS } \\
\text { Catechol }\end{array}$ & $\begin{array}{l}\mathrm{pH}-5.0 \\
\text { Temp- } 25^{\circ} \mathrm{C}\end{array}$ & $\begin{array}{l}\mathrm{NaCl}-1 \mathrm{M} \\
\mathrm{DMSO}-30 \% \mathrm{v} / \mathrm{v} \\
\text { Twin-80-1\% v/v }\end{array}$ & $\begin{array}{l}1.98 \pm 0.08 \\
2.84 \pm 0.17 \\
2.19 \pm 0.05 \\
2.81 \pm 0.13\end{array}$ & [59] \\
\hline Acinetobacter sp. & n-Propanol & $\begin{array}{l}\mathrm{pH}-2.0 \\
\text { temp- }-60^{\circ} \mathrm{C}\end{array}$ & NM & 1.571 & {$[60]$} \\
\hline Acinetobacter calcoacetius & n-Propanol_-100 mM & $\begin{array}{l}\mathrm{pH}-1.0 \\
\text { temp-70 }\end{array}$ & NM & 0.045 & {$[61]$} \\
\hline Deinococcus radiothilus & 2,4-Dichlorophenol & Time -3 days & NM & 0.300 & {$[62]$} \\
\hline Acinetobacter sp. SW 30 & n-Propanol-1.0 mM & $\begin{array}{l}\mathrm{pH}-2.0 \\
\text { Temp- }-40^{\circ} \mathrm{C}\end{array}$ & NM & 29.4 & [12] \\
\hline Bacillus mycoides & $\mathrm{H}_{2} \mathrm{O}_{2}-0.115 \mathrm{mM}$ & $\begin{array}{l}\mathrm{pH}-10.0 \\
\text { Temp-30 } \\
\text { Time- } 42 \mathrm{~h}\end{array}$ & $\begin{array}{l}\text { Cellulose } \\
\text { Yeast extract } \\
\mathrm{MnSO}_{4}\end{array}$ & 55.947 & Present study \\
\hline
\end{tabular}

NM not mentioned

conditions of ANOVA experiment. In the fit statistics of the response model of LiP activity, the value of adjusted $R^{2}$ was less than the $R^{2}$ value. Nooraziah and Tiagrajah [60] demonstrated that the adjusted $R^{2}$ value may be smaller than the $R^{2}$ when there are substantial terms in the model and the sample size is small. Some experimental factors might show to have significant emphasis in regulating enzymatic activity among all the interacting terms tested during RSM. Based on the $p$ value calculation in coefficient table, the two experimental factors substrate concentration and temperature have the most effectiveness in maintaining LiP activity. Similarly, in the study of Paul et al. [26], highest xylanase activity from the isolated xylanolytic bacterium Pseudomonas mohnii was reported to be mostly influenced by the factors such as $\mathrm{pH}$ and its substrate corn cob xylan concentration.

In this study, optimization of culture condition using RSM showed that the enzyme LiP from Bacillus mycoides has the maximum activity of $55.947 \mathrm{U} / \mathrm{mg}$ at $\mathrm{pH} 10.5$, temperature $30^{\circ} \mathrm{C}$, substrate concentration $0.115 \mathrm{mM}$, and incubation time $42 \mathrm{~h}$. Though an optimum $\mathrm{pH}$ of 10.5 was determined in which highest LiP activity (55.947 U/mg) was observed yet at $\mathrm{pH} 8.0$, an enhanced LiP activity of $37.155 \mathrm{U} / \mathrm{mg}$ has been recorded in two different experimental conditions where other three factors viz. temperature, substrate concentration, and incubation time differs. This observation suggests that an alkaline $\mathrm{pH}$ range between 8.0 and 10.5 may stimulate the increment in LiP activity of the strain Bacillus mycoides. Likewise, in a previous study by Falade et al. [61], LiP activity of $37.50 \mathrm{U} / \mathrm{mg}$ at optimum $\mathrm{pH}$ of 7.0 was recorded from the bacterium Ensifer adhaerens NWODO-2 (Table 4). From these observations, it can be concluded that maximum LiP activity is regulated under a broad range of alkaline $\mathrm{pH}$ condition. Other than alkaline $\mathrm{pH}$, maximum LiP activity has also been recorded in three optimized experimental factors viz. substrate $\left(\mathrm{H}_{2} \mathrm{O}_{2}\right)$ concentration of $0.115 \mathrm{mM}$, temperature at $30^{\circ} \mathrm{C}$, and incubation time of $42 \mathrm{~h}$. Vignali et al. [54], in their study, have reported an almost similar $\mathrm{H}_{2} \mathrm{O}_{2}$ concentration $(0.1 \mathrm{mM})$ as an optimized condition for the maximum LiP activity of $9.5 \mathrm{U} / \mathrm{mg}$ in Rhodococcus jostii (Table 4). Casciello et al. [62] have determined the LiP activity from the bacterium Nonomuraea 
gerenzanensis using the substrate $\mathrm{H}_{2} \mathrm{O}_{2}$ where LiP activity of $2.84 \pm 0.17 \mathrm{U} / \mathrm{mg}$ was recorded. The optimized LiP activity $(55.947 \mathrm{U} / \mathrm{mg})$ of $B$. mycoides as calculated in the present study was found to be 19.7 fold greater than the LiP activity observed in case of $N$. gerenzanensis as reported by Cascielo et al. Apart from $\mathrm{H}_{2} \mathrm{O}_{2}$, there are several substrates like n-propanol, 2,4-dichloro phenol, 2,6-dimethyl phenol, ABTS, catechol, kraft lignin, maize stover, wheat straw, and corn stover which have reported to be used as substrate to estimate the LiP activity in various bacterial species [56, 64-66]. The optimum temperature $\left(30^{\circ} \mathrm{C}\right)$ and incubation time $(42 \mathrm{~h})$ for maximum LiP activity as obtained in the present study is also in well agreement with the investigation conducted by Falade et al. [61], where maximum Lip activity was obtained at temperature $30^{\circ} \mathrm{C}$ and incubation time $48 \mathrm{~h}$ (Table 4). There are only two reports available till date on optimization study related to total bacterial LiP activity using RSM. Saha [67] demonstrated the optimization of LiP activity of the bacterium Paenibacillus mucilaginosus $\mathrm{S}-4$, and the maximum total enzyme activity was recorded as $22.825 \mathrm{U} / \mathrm{ml}$. Another work was conducted by Rizk et al. [68], where optimization of LiP production and its enzymatic activity have been demonstrated in aquatic bacterium, Alcaligenes aquatilis. For optimizing the enzyme activity and its production, Plackett-Burman design and Central composite design have been used respectively in this study. The results of the LiP activity in this study showed that the most optimum incubation time and $\mathrm{pH}$ were $24 \mathrm{~h}$ and 6.0 , respectively, in which the highest total LiP activity of $3.35 \mathrm{U} / \mathrm{ml}$ has been noted [59]. However, in the present work, the optimization of LiP activity using Box-Behnken design from the bacterium Bacillus mycoides isolated from forest soil sample is a new study as no such investigation has been undertaken previously. It is also noteworthy that in this present work, the highest LiP activity of $55.947 \mathrm{U} /$ mg was obtained from B. mycoides calculated in terms of specific activity of the enzyme. This specific LiP activity from $B$. mycoides is even greater than the LiP activity $(47.14 \pm 0.41 \mathrm{U} / \mathrm{mg})$ calculated using saw dust as substrate from the bacterium Bacillus sp. MABINYA-1 (Table 4) [57], and this is still highest among all the bacterial LiP activity reported till date. Therefore, it can be stated from these comparative results that the bacterial strain isolated from forest soil samples of SBR is an efficient LiP producing candidate which can serve in potent lignin biodegradation.

\section{Conclusion}

Current study depicted that the soils collected from the forests of Simlipal Biosphere Reserve (SBR) of Odisha, India, are a rich source of lignocellulolytic bacteria with high lignin peroxidase activity. The present study revealed the potential of the strain SLB10 for high lignin peroxidase enzyme production. The ligninolytic strain SLB10 obtained from the soil of SBR was identified as Bacillus mycoides through morphological, biochemical characterization, and $16 \mathrm{~S}$ rRNA sequencing. The lignin peroxidase enzyme activity of this bacterium was $31.711 \mathrm{U} / \mathrm{mg}$ under unoptimized condition. The optimization through RSM the ligninolytic activity resulted in a higher lignin peroxidase activity $(55.947 \mathrm{U} / \mathrm{mg})$ of the ligninolytic bacterium B. mycoides. The enzyme production showed approximately 1.76 folds enhance over the un-optimized condition. Individually, the presence of cellulose, yeast extract, and $\mathrm{MnSO}_{4}$ in the culture medium of B. mycoides promotes both the LiP activity and dye decolourization. The present study thus highlights the potential of the newly isolated bacterium B. mycoides from SBR for possible use for large-scale enzyme production through adoption of appropriate technology. The enzyme production from this bacterium can be used for industrial purpose including bioethanol production, textile industries, toxicity reduction in pulp and paper mill effluents, cosmetology, and dermatology through its novel mechanism. However, additional work related to protein characterizations and pilot scale production of the LiP enzyme from this bacterium need to be studied.

\section{Abbreviations \\ SBR: Simlipal Biosphere Reserve; SLB: Simlipal ligninolytic bacteria; RSM: Response surface methodology; $\mathrm{KCl}$ : Potassium chloride; $\mathrm{MgSO}_{4}$ : Magnesium sulphate; $\mathrm{MnSO}_{4}$ : Manganese sulphate; $\mathrm{ZnSO}_{4}$ : Zinc sulphate; $\mathrm{CuSO}_{4}$ : Copper sulphate; $\mathrm{FeSO}_{4}$ : Ferrous sulphate; $\mathrm{NaCl}$ : Sodium chloride; $\mathrm{CaCl}_{2}$ : Calcium chloride; $\mathrm{CoCl}_{2}$ : Cobalt chloride; $\mathrm{NaNO}_{3}$ : Sodium nitrate; $\mathrm{NH}_{4} \mathrm{NO}_{3}$ : Ammonium nitrate; $\mathrm{H}_{2} \mathrm{SO}_{4}$ : Sulphuric acid; MSM-L: Minimal salt medium-lignin; LCB: Ligno- cellulosic biomass.}

\section{Acknowledgments}

The authors are grateful to the HOD of Department of Biotechnology, Maharaja Sriram Chandra Bhanja Deo University, Baripada, Odisha, India, for providing infrastructure facilities to conduct the experimental works. The authors are also thankful to the Forest and Environment Department, Government of Odisha, India, for the permission of soil sample collection from the buffer areas of Simlipal Biosphere Reserve and Forest officers and attendants for extending their cooperation during the field work.

\section{Authors' contributions}

SR and MP conducted major part of the experiments, investigated the results, analysed the data, validated the results with related previous works, and contributed in the writing of the original manuscript and formatting. HKB performed parts of the experiments, analysed the data, and helped in the formal writing. HT supervised the whole work, conceptualized the research, and guided the writing and editing of the manuscript. All authors read and approved the manuscript.

\section{Funding}

This work did not receive funding from any organization or institution.

Availability of data and materials

All data generated or analyzed during this study are included in this article. 


\section{Declarations}

Ethics approval and consent to participate

Not applicable.

\section{Consent for publication}

Not applicable.

\section{Competing interests}

The authors declare that they have no competing interests.

Received: 25 February 2021 Accepted: 6 December 2021

Published online: 03 January 2022

\section{References}

1. Ritchie H, Roser M (2017) Fossil fuels. In: Our World in Data

2. Moreno A, Sipponen MH (2020) Lignin-based smart materials: a roadmap to processing and synthesis for current and future applications. Mater Horizons 7(9):2237-2257

3. Koh LP, Ghazoul J (2008) Biofuels, biodiversity, and people: understanding the conflicts and finding opportunities. Biol Conserv 14(10):2450-2460

4. Bindra S, Sharma R, Khan A, Kulshrestha S (2017) Renewable energy sources in different generations of bio-fuels with special emphasis on microalgae derived biodiesel as sustainable industrial fuel Model. Biosci Biotechnol Res Asia 14(1):259-274

5. Janusz G, Pawlik A, Sulej J, Świderska-Burek U, Jarosz-Wilkołazka A, Paszczyński A (2017) Lignin degradation: microorganisms, enzymes involved, genomes analysis and evolution. FEMS Microbiol Rev 41(6):941-962

6. Datta R, Kelkar A, Baraniya D, Molaei A, Moulick A, Meena RS, Formanek $P(2017)$ Enzymatic degradation of lignin in soil: a review. Sustainability 9(7):1163

7. Xu Z, Lei P, Zhai R, Wen Z, Jin M (2019) Recent advances in lignin valorization with bacterial cultures: microorganisms, metabolic pathways, and bio-products. Biotechnol Biofuels 12(1):1-19

8. Sharma R, Singh VP, Singh D, Yusuf F, Kumar A, Vishwakarma RA, Chaubey A (2016) Optimization of nonribosomal peptides production by a psychrotrophic fungus: Trichoderma velutinum ACR-P1. Appl Microbiol Biotechnol 100:9091-9102

9. Kirk TK, Farrell RL (1987) Enzymatic "combustion": the microbial degradation of lignin. Annu Rev Microbiol 41(1):465-501

10. Abdel-Hamid AM, Solbiati JO, Cann IK (2013) Insights into lignin degradation and its potential industrial applications. Adv Appl Microbiol 82:1-28

11. Blanchette RA (1995) Degradation of the lignocellulose complex in wood. Can J Bot 73(S1):999-1010

12. Singh R, Shedbalkar UU, Nadhe SB, Wadhwani SA, Chopade BA (2017) Lignin peroxidase mediated silver nanoparticle synthesis in Acinetobacter sp. AMB Express 7:1-10

13. Bugg TD, Ahmad M, Hardiman EM, Rahmanpour R (2011) Pathways for degradation of lignin in bacteria and fungi. Nat Prod Rep 28:1883-1896

14. Bilal M, Asgher M (2016) Biodegradation of agrowastes by lignocellulolytic activity of an oyster mushroom, Pleurotus sapidus. J Natl Sci Found 44(4):399-407

15. Padma N, Sudha $H$ (2013) Optimization of lignin peroxidase, manganese peroxidase, and lac production from Ganoderma lucidum under solid state fermentation of pineapple leaf. Bioresources 8(1):250-271

16. Vandana T, Rao RG, Kumar SA, Swaraj S, Manpal S (2018) Enhancing production of lignin peroxidase from white rot fungi employing statistical optimization and evaluation of its potential in delignification of crop residues. Int J Curr Microbiol App Sci 7:2599-2621

17. Yasmeen Q, Asgher M, Sheikh MA, Nawaz H (2013) Optimization of ligninolytic enzymes production through response surface methodology. Bioresources 8(1):944-968

18. Zanirun Z, Abd-Aziz S, Ling FH, Hassan MA (2009) Optimisation of lignin peroxidase production using locally isolated Pycnoporus sp. through factorial design. Biotechnol 8(3):296-305
19. Abd-Elsalam HE, El-Hanafy AA (2009) Lignin biodegradation with ligninolytic bacterial strain and comparison of Bacillus subtilis and Bacillus sp. isolated from Egyptian soil. Am Eurasian J Agric Environ Sci 5(1):39-44

20. Bandounas L, Wierckx NJ, de Winde JH, Ruijssenaars HJ (2011) Isolation and characterization of novel bacterial strains exhibiting ligninolytic potential. BMC Biotechnol 11(1):94

21. Chang YC, Choi D, Takamizawa K, Kikuchi S (2014) Isolation of Bacillus sp. strains capable of decomposing alkali lignin and their application in combination with lactic acid bacteria for enhancing cellulase performance. Bioresour Technol 152:429-436

22. Harith ZT, Ibrahim NA, Yusoff N (2014) Isolation and identification of locally isolated lignin degrading bacteria. J Sustain Sci Manag $9(2): 114-118$

23. Melo-Nascimento AODS, Treumann C, Neves C, Andrade E, Andrade AC, Edwards R, Dinsdale E, Bruce T (2018) Functional characterization of ligninolytic Klebsiella spp. strains associated with soil and freshwater. Arch Microbiol 200(8):1267-1278

24. Naz S (2016) Study of ligninolytic bacteria isolation and characterization from Kuthrel agro field of Bhilai-Durg region. Int J Curr Microbiol App Sci 5(12):141-150

25. Mishra RC, Sahoo HK, Pani DR, Bhandari DC (2013) Genetic resources of wild tuberous food plants traditionally used in Similipal Biosphere Reserve, Odisha, India. Genet Resour Crop Evol 60(7):2033-2054

26. Paul M, Nayak DP, Thatoi H (2020) Optimization of xylanase from Pseudomonas mohnii isolated from Simlipal Biosphere Reserve, Odisha, using response surface methodology. J Genet Eng Biotechnol 18(1):1-19

27. Paul M, Meher SR, Giri S, Thatoi H (2021) Isolation, screening, and evaluation of cellulase-producing bacteria from the soil of Similipal Biosphere Reserve for biofuel production from lignocellulosic biomass. In: Advances in Bioprocess Engineering and Technology. Springer, Singapore, pp 457-466

28. Allen CD, Grethien HE. (1983) Process studies for Enzymatic hydrolysis using high solids slurries of acid pretreated mixed hardwood. In Biotechnology and Bioengineering Symposium (United States) 13 CONF830567-. Dartmouth Coll., Hanover.

29. Chandra R, Raj A, Purohit HJ, Kapley A (2007) Characterisation and optimisation of three potential aerobic bacterial strains for kraft lignin degradation from pulp paper waste. Chemosphere 67(4):839-846

30. Sasikumar V, Priya V, Shankar CS, Sekar SD (2014) Isolation and preliminary screening of lignin degrading microbes. J Acad Indust Res 3(6):291-294

31. Rahman NHA, Abd Aziz S, Hassan MA (2013) Production of ligninolytic enzymes by newly isolated bacteria from palm oil plantation soils. Bioresources 8(4):6136-6150

32. Ahmed AAQ, Babalola OO, Mckay T (2016) Lignin degradation by two isolated Bacillus spp. and their co-culture potential in the production of platform chemicals from lignin. Chemtech 16:40

33. Prabhu PC, Udayasoorian C (2005) Biodecolorisation of phenolic paper mill effluent by ligninolytic fungus Trametes versicolor. Aust J Biol Sci 5(5):558-561

34. Bholay AD, Borkhataria BV, Jadhav PU, Palekar KS, Dhalkari MV, Nalawade PM (2012) Bacterial lignin peroxidase: a tool for biobleaching and biodegradation of industrial effluents. Univers J Environ Res Technol 2(1):58-64

35. Coico R (2006) Gram staining. Curr Protoc Microbiol (1):A-3C

36. Whitman WB (2015) Taxonomic outline of bacteria and archaea. Bergey's manual of systematics of archaea and bacteria. World J Microbiol Biotechnol 21:575-581

37. Sambrook J, Russel D (2001) Rapid isolation of yeast DNA. In: Sambrook J, Russel DW (eds) Molecular cloning, a laboratory manual. Cold Spring Harbor Laboratory, New York, pp 631-632

38. Huang X, Madan A (1999) CAP3: A DNA sequence assembly program. Genome Res 9(9):868-877

39. Altschul SF, Gish W, Miller W, Myers EW, Lipman DJ (1990) Basic local alignment search tool. J Mol Biol 215:403-410

40. Kumar S, Stecher G, Tamura K (2016) MEGA7: Molecular Evolutionary Genetics Analysis version 7.0 for bigger datasets. Mol Biol Evol 33(7):1870-1874

41. Felsenstein J (1985) Confidence limits on phylogenies: an approach using the bootstrap. Evolution 39(4):783-791

42. Tamura K, Peterson D, Peterson N, Stecher G, Nei M, Kumar S (2011) MEGA5: molecular evolutionary genetics analysis using maximum likelihood, evolutionary distance, and maximum parsimony methods. Mol Biol Evol 28(10):2731-2739 
43. Sharma S, Singh P (2014) Isolation and characterization of Galactosidase enzyme producing microbe and optimization of its enzyme activity under different culture condition. Int J Curr Microbiol App Sci 3(7):148-155

44. Venkateswarulu TC, Prabhakar KV, Kumar RB (2017) Optimization of nutritional components of medium by response surface methodology for enhanced production of lactase. 3. Biotech 7(3):1-9

45. Garai D, Kumar V (2013) Response surface optimization for xylanase with high volumetric productivity by indigenous alkali tolerant Aspergillus candidus under submerged cultivation. 3. Biotech 3(2):127-136

46. Smitha KV, Pradeep BV (2017) Application of Box-Behnken design for the optimization of culture conditions for novel fibrinolytic enzyme production using bovine blood clot by Bacillus altitudinis S-CSR 0020. J Pure Appl Microbiol 11(3):1447-1456

47. Mohapatra S, Padhy S, Mohapatra PKD, Thatoi H (2018) Enhanced reducing sugar production by saccharification of lignocellulosic biomass, Pennisetum species through Cellulase from a newly isolated Aspergillus fumigatus. Bioresour Technol 253:262-272

48. Denise BM, Maria LA, Elba B, Julio SAN, Sergio HK (1996) Colorimetric assay for lignin peroxidase activity determination using methylene blue as substrate. Biotechnol Tech 10(4):273-276

49. Jadhav PU, Bholay AD, Shindikar K (2016) Bacterial lignin peroxidase in biobleaching of lignin-mimicking indicator dyes. Int J Pure App Biosci 4(4):84-92

50. Baldrian P, Kolarık M, Stursova M, Kopecky J, Valaskova V, Vetrovsky $\mathrm{T}$ (2012) Active and total microbial communities in forest soil are largely different and highly stratified during decomposition. ISME J 6(2):248-258

51. Nannipieri P, Ascher J, Ceccherini MT, Landi L, Pietramellara G, Renella G (2017) Microbial diversity and soil functions. Eur J Soil Sci 68(1):12-26

52. Tian JH, Pourcher AM, Peu P (2016) Isolation of bacterial strains able to metabolize lignin and lignin-related compounds. Lett Appl Microbiol 63(1):30-37

53. Alam MZ, Mansor MF, Jalal KCA (2009) Optimization of decolorization of methylene blue by lignin peroxidase enzyme produced from sewage sludge with Phanerocheate chrysosporium. J Hazard Mater 162(2-3):708-715

54. Vignali E, Tonin F, Pollegioni L, Rosini E (2018) Characterization and use of a bacterial lignin peroxidase with an improved manganese-oxidative activity. Appl Microbiol Biotechnol 102(24):10579-10588

55. Eastman AW (2015) Genomic analyses of Paenibacillus polymyxa CR1, a bacterium with potential applications in biomass degradation and biofuel production

56. Ramachandra M, Crawford DL, Hertel G (1988) Characterization of an extracellular lignin peroxidase of the lignocellulolytic actinomycete Streptomyces viridosporus. Appl Environ Microbiol 54(12):3057-3063

57. Falade AO, Mabinya LV, Okoh Al, Nwodo UU (2020) Agroresidues enhanced peroxidase activity expression by Bacillus sp. MABINYA-1 under submerged fermentation. Bioresourc Bioprocess 7(1):1-9

58. Doddapaneni K, Tatineni R, Potumarthi R, Mangamoori LN (2007) Optimization of media constituents through response surface methodology for improved production of alkaline proteases by Serratia rubidea. J Chem Technol Biotechnol 82(8):721-729

59. Haaland PD (1989) Experimental design in biotechnology, vol 105. CRC press, New York

60. Nooraziah A, Tiagrajah VJ (2014) A study on regression model using response surface methodology. In: Applied Mechanics and Materials, vol 666. Trans Tech Publications Ltd, Switzerland, pp 235-239

61. Falade A, Jaouani A, Mabinya L, Okoh A, Nwodo U (2019) Exoproduction and molecular characterization of peroxidase from Ensifer adhaerens. Appl Sci 9(15):3121

62. Casciello C, Tonin F, Berini F, Fasoli E, Marinelli F, Pollegioni L, Rosini E (2017) A valuable peroxidase activity from the novel species Nonomuraea gerenzanensis growing on alkali lignin. Biotechnol Rep 13:49-57

63. Yolmeh M, Jafari SM (2017) Applications of response surface methodology in the food industry processes. Food Bioproc Tech 10(3):413-433

64. Ghodake GS, Kalme SD, Jadhav JP, Govindwar SP (2009) Purification and partial characterization of lignin peroxidase from Acinetobacter calcoaceticus NCIM 2890 and its application in decolorization of textile dyes. Appl Biochem Biotechnol 152(1):6-14
65. Kharayat $Y$, Thakur IS (2012) Isolation of bacterial strain from sediment core of pulp and paper mill industries for production and purification of lignin peroxidase (LiP) enzyme. Biorem J 16(2):125-130

66. Wadhwani SA, Gorain M, Banerjee P, Shedbalkar UU, Singh R, Kundu GC, Chopade BA (2017) Green synthesis of selenium nanoparticles using Acinetobacter sp. SW30: optimization, characterization and its anticancer activity in breast cancer cells. Int J Nanomedicine 12:6841

67. Saha A. (2012) Biochemical and molecular characterization of bacterial consortium of municipal solid wastes. Ph.D. Thesis, University of Delhi.

68. Rizk NMH, Eldourghamy AS, Aly SA, Sabae SZ, Sobhy A (2020) Production of lignin peroxidase from aquatic bacteria, Alcaligenes aquatilis. Egypt J Aquat Biol Fisheries 24(3):213-223

\section{Publisher's Note}

Springer Nature remains neutral with regard to jurisdictional claims in published maps and institutional affiliations.

\section{Submit your manuscript to a SpringerOpen ${ }^{\circ}$ journal and benefit from:}

- Convenient online submission

- Rigorous peer review

- Open access: articles freely available online

- High visibility within the field

- Retaining the copyright to your article

Submit your next manuscript at $\boldsymbol{\nabla}$ springeropen.com 